\title{
Hydrothermal-sedimentary dolomite - a case from the Middle Permian in eastern Junggar Basin, China
}

\author{
Shuai Zhang ${ }^{1,2,3,4}$, Yi-Qun Liu' ${ }^{1,2^{*}}$, Hong $\mathrm{Li}^{1,2}$, Xin Jiao ${ }^{1,2}$ and Ding-Wu Zhou ${ }^{1,2}$
}

\begin{abstract}
The Middle Permian Lucaogou Formation in the Jimusar Sag, eastern Junggar Basin, NW China, was deposited in a salt lake within an intracontinental rift basin with intense hydrothermal activity. Hydrothermal-sedimentary dolomite in the form of three types of dolostones, namely, analcime-feldspar dolostone (AFD), silicic dolostone (SD) and buddingtonite-albite dolostone (BAD), related to syn-sedimentary hydrothermal activity at lake bottom was discovered. The characteristics and formation mechanism of the dolomite were studied based on micron-scale petrographic and isotopic geochemical research. The syn-depositional formation of these dolostones was indicated by their rock-mineral features and syn-sedimentary deformation stage. The dolomite was composed of relatively poorly ordered proto-dolomite crystals with micron-sized spherical or sub-spherical morphology and coexisted with hydrothermal minerals, including analcime, buddingtonite, albite and chalcedony. Albite clasts were replaced by the dolomite, indicating high-temperature conditions during formation. The remarkably low strontium isotopic compositions of the dolostones $\left({ }^{87} \mathrm{Sr} /{ }^{86} \mathrm{Sr}\right.$ with an average of 0.705687$)$ indicated that mantle-derived materials might have involved in the ore-forming fluid. The dolostones had positive $\delta^{13} C_{P D B}$ values (with an average of $6.94 \%$ ) and negative $\delta^{18} \mathrm{O}_{\mathrm{PDB}}$ values (with an average of $-8.12 \%$ ). Based on the $\delta^{18} \mathrm{O}_{\mathrm{PDB}}$ values, the formation temperatures of the dolomite were at least $\sim 25^{\circ} \mathrm{C}$ higher than those of the penecontemporaneous dolomite in the Lucaogou Formation in the study area. It is concluded that the dolomite precipitated from hydrothermal fluid erupting at the lake bottom. The possible genetic models are described. We suggest that the hydrothermalsedimentary dolomite is an important genetic type, and this study may help increase the awareness of this understudied type of dolomite.
\end{abstract}

Keywords: Dolomite genesis, Hydrothermal sedimentary dolomite, Permian, Lucaogou Formation, Jimusar Sag, Junggar Basin

\section{Introduction}

How dolomite forms under near-surface conditions has been puzzling ever since dolomite was first reported by Dolomieu (1791), and this issue is commonly referred to as the "dolomite problem" (Land 1998; Arvidson and Mackenzie 1999; Machel 2004; Bontognali 2019). The

\footnotetext{
* Correspondence: liu-yiqun@263.net

'State Key Laboratory of Continental Dynamics, Northwest University, Xi'an

710069, Shaanxi Province, China

${ }^{2}$ Department of Geology, Northwest University, Xi'an 710069, Shaanxi

Province, China

Full list of author information is available at the end of the article
}

kinetic difficulty of dolomite formation can be overcome at high temperatures (Machel 2004). Ordered dolomite can crystallize directly from solution at high temperatures in the laboratory (e.g., $>140^{\circ} \mathrm{C}$, Rodriguez-Blanco et al. 2015). Under natural conditions, dolomite forming at higher-than-ambient temperatures is called hydrothermal dolomite (Machel and Lonnee 2002) and is commonly inferred to form through the replacement of precursors under the influence of fault-controlled hydrothermal fluids in a diagenetic stage (e.g., Boni et al. 2000; Al-Aasm 2003; Luczaj et al. 2006; Feng et al. 2017). In

\section{Springer Open}

(c) The Author(s). 2020 Open Access This article is licensed under a Creative Commons Attribution 4.0 International License, which permits use, sharing, adaptation, distribution and reproduction in any medium or format, as long as you give appropriate credit to the original author(s) and the source, provide a link to the Creative Commons licence, and indicate if changes were made. The images or other third party material in this article are included in the article's Creative Commons licence, unless indicated otherwise in a credit line to the material. If material is not included in the article's Creative Commons licence and your intended use is not permitted by statutory regulation or exceeds the permitted use, you will need to obtain permission directly from the copyright holder. To view a copy of this licence, visit http://creativecommons.org/licenses/by/4.0/. 
extensional settings, hydrothermal fluids from deep in a basin can move upward through faults and finally erupt at the basin floor in either marine or lacustrine settings, resulting in a "black smoker" composed of metal sulfides (e.g., the "Rainbow" vent field, Charlou et al. 2002) or a "white smoker" composed of sulfates, carbonates and silicon dioxide (e.g., the "Lost City" vent field, Kelley et al. 2001). Modern dolomites precipitating under such conditions have been reported (e.g., Shanks III 2001; Eickmann et al. 2009). However, they are relatively rare, probably due to the scarcity of precursors for dolomitization or proper conditions for direct crystallization.

The Miocene dolomite microcrystals in the Inner Dinarides of Yugoslavia were found to have crystallized directly from hydrothermal solutions at the bottom of a lake within a large peridotite-serpentinite massif and were named "hydrothermal-sedimentary dolomite" (Ilich 1974). This study was the first to investigate hydrothermal-sedimentary dolomite in the world. Nevertheless, hydrothermal-sedimentary dolomites did not become widely known until Zheng et al. (2003) claimed, nearly 30 years later, that the Early Cretaceous dolomites in the Jiuquan Basin of China were of hydrothermalsedimentary genesis and belonged to a lacustrine white smoker. Since then, more hydrothermal-sedimentary rocks comprising dolomite and other hydrothermal minerals have been found in Chinese basins (Zheng et al. 2006, 2018; Dai et al. 2008; Liu et al. 2010, 2012; Zhang et al. 2010; Guo et al. 2012; Wen et al. 2013; Fu et al. 2015; Zhong et al. 2015, 2018; Chang et al. 2016; Tao et al. 2016; Jiao et al. 2017a, 2018, 2020; Li et al. 2017a; Chen et al. 2018; Su et al. 2020; Yang et al. 2020). Generally, hydrothermal-sedimentary rocks are composed of ankerite or ferrodolomite microcrystals; low-temperature hydrothermal minerals, such as zeolite, albite, barite and quartz; and a few metal sulfide minerals, such as pyrite, galenite and sphalerite. They are characterized by laminated and mesh vein structures, syn-sedimentary deformation structures and hydrothermal intraclastic textures. On the one hand, hydrothermal-sedimentary dolomite is an important genetic type of dolomite and is of great significance for clarifying the formation of dolomites. On the other hand, it also possesses important economic value both as a mineral product (Ilich 1974) and as oil and gas reservoirs (Zheng et al. 2003). Thus, it is necessary to investigate this understudied type of dolomite from both scientific and application perspectives.

Hydrothermal-sedimentary rocks have generally been identified according to their mineral assemblages, macroscopic structures and geochemical characteristics. However, few studies have focused on the dolomite itself. In the meanwhile, most studies have overlooked that more direct and detailed evidence of the formation mechanism could be found by investigating the microscopic features of the dolomites and their associated minerals. Given the scarcity of hydrothermalsedimentary dolomites in modern environments and the complexity of dolomite formation, it is urgent to carry out micro-scale petrographical and isotopic geochemical research on hydrothermal-sedimentary dolomites throughout geological time to shed new light on this rare type of dolomite.

The Middle Permian Lucaogou Formation in the Jimusar Sag, eastern Junggar Basin, Northwest China, was deposited in a salt lake within an intracontinental rift basin with intense hydrothermal activity. Lots of sedimentary exhalative rocks that are characterized by the presence of coarse-grained angular calcites and calcite layers in a fine-grained matrix have been found in the Lucaogou Formation (Li et al. 2017a; Liu et al. 2018, 2019). In this study, hydrothermalsedimentary dolomites were discovered in the Lucaogou Formation in the Jimusar Sag. To further uncover the formation mechanisms and increase the awareness of this understudied type of dolomite, systematic investigations have been conducted in the present study. The microscopic features are presented, and the ore-forming fluid characteristics and detailed formation mechanisms are discussed based on micron-scale petrographical and isotopic geochemical research.

\section{Geological setting}

The Junggar Basin, located in the north of the Xinjiang Uygur Autonomous Region (Fig. 1), NW China, and surrounded by mountain ranges, has a basement composed of pre-Carboniferous micro-blocks, ocean basins and island arcs (Bian et al. 2010). During the Late Carboniferous, the ocean basin between the Junggar Block and the Siberian Block to the north and the basin between the Junggar Block and the Tarim-Middle Tianshan Block to the south both closed (Li et al. 1990; Carroll et al. 1995). Consequently, seawater retreated from the Junggar Basin area, with seawater remaining only in the Bogda Rift in the southeast and connecting with the open ocean in the Early Permian (Wartes et al. 2002). An intraplate extension stage began in the northern Xinjiang area (Fang et al. 2006; Zhou et al. 2006; Lu 2007), and the eastern Junggar Basin began to evolve into a rift basin (Fang et al. 2006). A palaeo-megalake existed in the Junggar Basin and Turpan-Hami Basin (Wartes et al. 2002), and a set of fine-grained lacustrine sedimentary rocks with total organic carbon (TOC) contents of more than 20\% and a thickness of nearly $2 \mathrm{~km}$ formed (Graham et al. 1990; Carroll et al. 1992). The Permian strata in the Jimusar Sag, comprising thickly laminated deposits of 


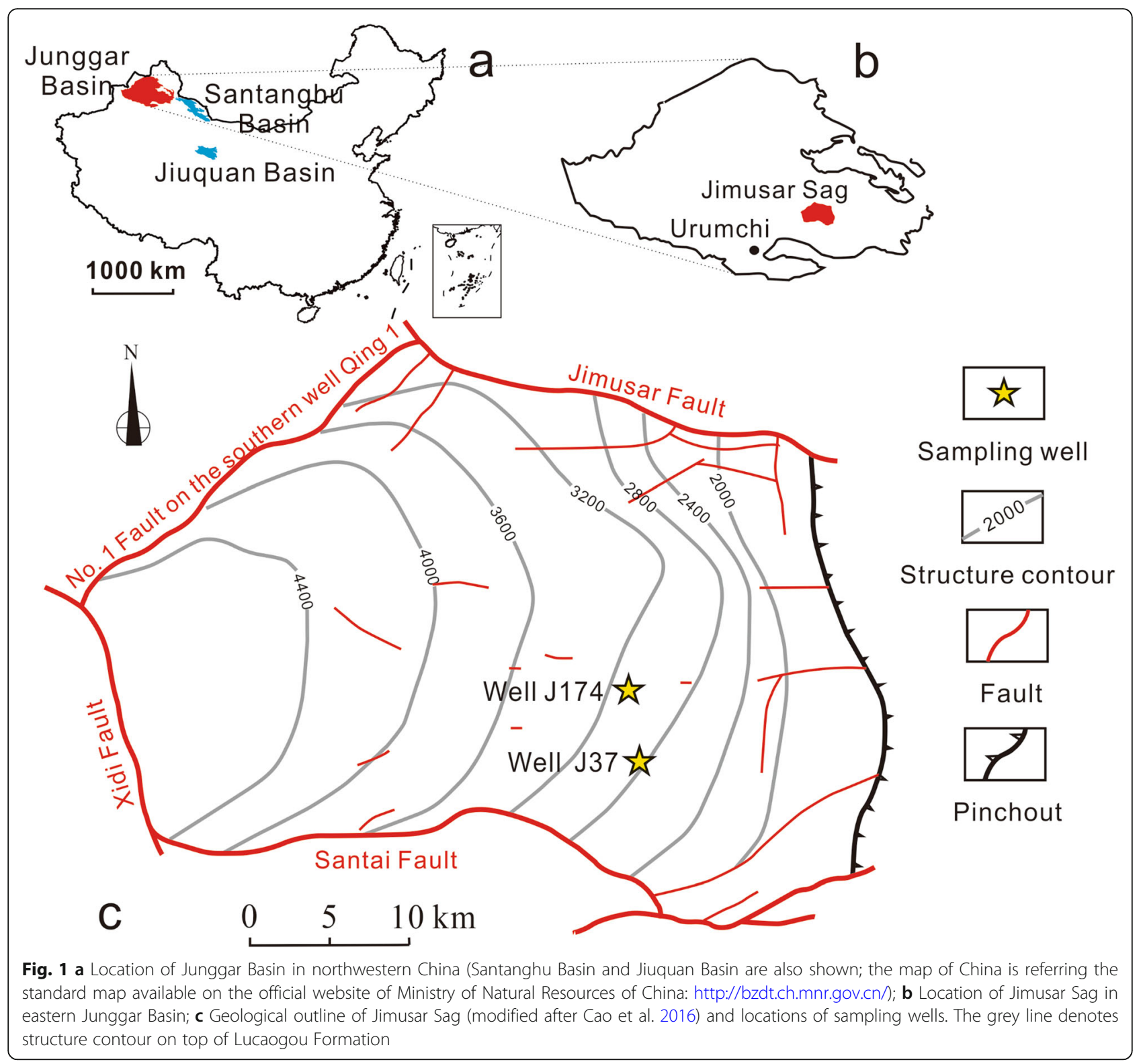

Table 1 Strata outcropped in Jimusar Sag, eastern Junggar Basin, Northwest China

\begin{tabular}{|c|c|c|c|c|}
\hline Eonothem & System & Series & Group & Formation \\
\hline \multirow{2}{*}{ Mesozoic } & \multirow{2}{*}{ Triassic } & \multirow{2}{*}{ Lower } & \multirow{2}{*}{$\begin{array}{c}\text { Upper } \\
\text { Cangfanggou }\end{array}$} & Shaofanggou \\
\hline & & & & Jiucaiyuan \\
\hline \multirow{4}{*}{ Paleozoic } & \multirow{3}{*}{ Permian } & Upper & \multirow{3}{*}{$\begin{array}{c}\text { Lower } \\
\text { Cangfanggou }\end{array}$} & Wutonggou \\
\hline & & \multirow{2}{*}{ Middle } & & Lucaogou \\
\hline & & & & Jiangjunmiao \\
\hline & Carboniferous & Lower & & Batamayineishan \\
\hline
\end{tabular}


semi-deep to deep lake facies, represent the eastern part of the sedimentary succession.

The Carboniferous and Permian strata in the Jimusar Sag are composed of, from bottom to top, the Lower Carboniferous Batamayineishan Formation, the Middle Permian Jiangjunmiao Formation, the Middle Permian Lucaogou Formation and the Upper Permian Wutonggou Formation (Table 1). The Lucaogou Formation consists of fine-grained lacustrine sedimentary rocks, mainly dolomitic rocks and sedimentary tuffs, formed by mechanical sedimentation, chemical sedimentation, volcanism (Shao et al. 2015; Xi et al. 2015; Song et al. 2017; Yang et al. 2019) and hydrothermal exhalative sedimentation (Jiang et al. 2015; Li et al. 2017a; Liu et al. 2018, 2019). Taking the maximum flooding surface as a boundary, the Lucaogou Formation $\left(\mathrm{P}_{2} \mathrm{l}\right)$ is divided into two sections: lower $\left(\mathrm{P}_{2} \mathrm{l}_{1}\right)$ and upper $\left(\mathrm{P}_{2} \mathrm{l}_{2}\right)$. A "sweet spot body" has been identified in both sections (Jiang et al. 2015; Cao et al. 2016). The dolomites in the dolomitic rocks present as euhedral-subhedral microcrystals mixed with tuff and terrestrial clasts and are considered to have a penecontemporaneous origin (Zhang et al. 2018). The syn-sedimentary hydrothermal activity in the studied strata is indicated by sedimentary exhalative rocks composed of coarse-grained angular calcites and calcite layers in a fine-grained matrix ( $\mathrm{Li}$ et al. 2017a; Liu et al. 2018, 2019).

\section{Material and methods}

Core samples from Well J174 and Well J37 were observed carefully, and two dolostone samples (J37-A and J37-B) from Well J37 and one dolostone sample (J174-A) from Well J174 were selected. The mineral compositions and sedimentary structures were preliminarily studied by thin section observation using a polarizing microscope. X-ray diffraction (XRD) analysis was used to identify the specific mineral composition and content and to determine the crystal structures of the dolomites. However, because of the heterogeneous distribution of minerals and their fine grain sizes, it is difficult to obtain accurate bulk mineral contents of samples J37-A and J174-A by XRD analysis of the rock powders extracted locally or by thin section observations alone. Thus, based on the XRD analysis results of different parts of the samples extracted with a micro-drill, the mineral contents of the whole rock were estimated by thin section observations and backscattered electron imaging combined with energy-dispersive spectroscopy (EDS). Additionally, the major element compositions of the minerals were analysed by electron probe microanalysis (EPMA). The morphology of minerals was observed using backscattered electron imaging with the electron probe and a FEI Quanta 400 FEG scanning electron microscope (SEM) (astigmatism $\leq 50 \mu \mathrm{m}$; magnification factor $=7$ to $10^{6}$; image resolution $\leq 3.5$ $\mathrm{nm}$; the State Key Laboratory of Continental Dynamics of Northwest University). The XRD and electron probe analyses were conducted in the Experimental Test Center of Xi'an Center of Geological Survey. Strontium isotope analysis was carried out for the inspection of ore-forming characteristics on a $\mathrm{Nu}$ Plasma multi-collector inductively coupled plasma mass spectrometer (MC-ICP-MS) produced by $\mathrm{Nu}$ Instruments at the State Key Laboratory of Continental Dynamics of Northwest University. Carbon and oxygen isotopic analyses were performed at the Institute of Earth Environment, Chinese Academy of Sciences, with a MAT252 stable isotope ratio mass spectrometer. The analytical precision of $\delta^{13} \mathrm{C}$ is better than \pm $0.06 \%$, and that of $\delta^{18} \mathrm{O}$ is better than $\pm 0.08 \%$.

The samples for dolomite crystal structure analysis by XRD should have a dolomite content of more than $40 \%$ and no clay minerals. The dolomite contents of the samples for carbon and oxygen isotopic analysis and strontium isotopic analysis should be more than $35 \%$ and $90 \%$, respectively, and no other carbonates should be present. Sometimes, the dolomite content of the bulk samples cannot meet the requirements due to the heterogeneous distribution of the dolomite. Thus, dolomite was extracted with a micro-drill based on thin section and backscattered image observations. In addition, three euhedral-subhedral micro-crystalline dolostones from Well J174 interpreted as having a penecontemporaneous origin (Zhang et al. 2018) were chosen for carbon, oxygen and strontium isotopic analyses for comparative study.

\section{Results}

\subsection{Occurrence of the sedimentary exhalative rocks and dolostones}

The Middle Permian Lucaogou Formation in the study area is composed of a mixed sedimentary succession of tuffaceous dolostone, dolomitic rocks, siltstone and mudstone (Fig. 2a). The sedimentary exhalative rocks that were identified in 26 wells in the Jimusar Sag are the most common geological records of the Permian syn-sedimentary hydrothermal activity in the study area (Li et al. 2017a; Liu et al. 2018). In Well J174 and Well J37, the sedimentary exhalative rocks occur as interbeds with thicknesses of $0.5 \mathrm{~cm}$ to $4 \mathrm{~cm}$ within dolomitic rocks, tuffaceous dolostones and mudstones. Their alternation with other normal sediments reflects frequent but discontinuous eruptions of hydrothermal fluids, as hydraulic pressure is known to play a key role in typical subaqueous hydrothermal activity (Fisher and Schmincke 2012). The calcites in the sedimentary exhalative rocks show two occurrences in the interbeds: 


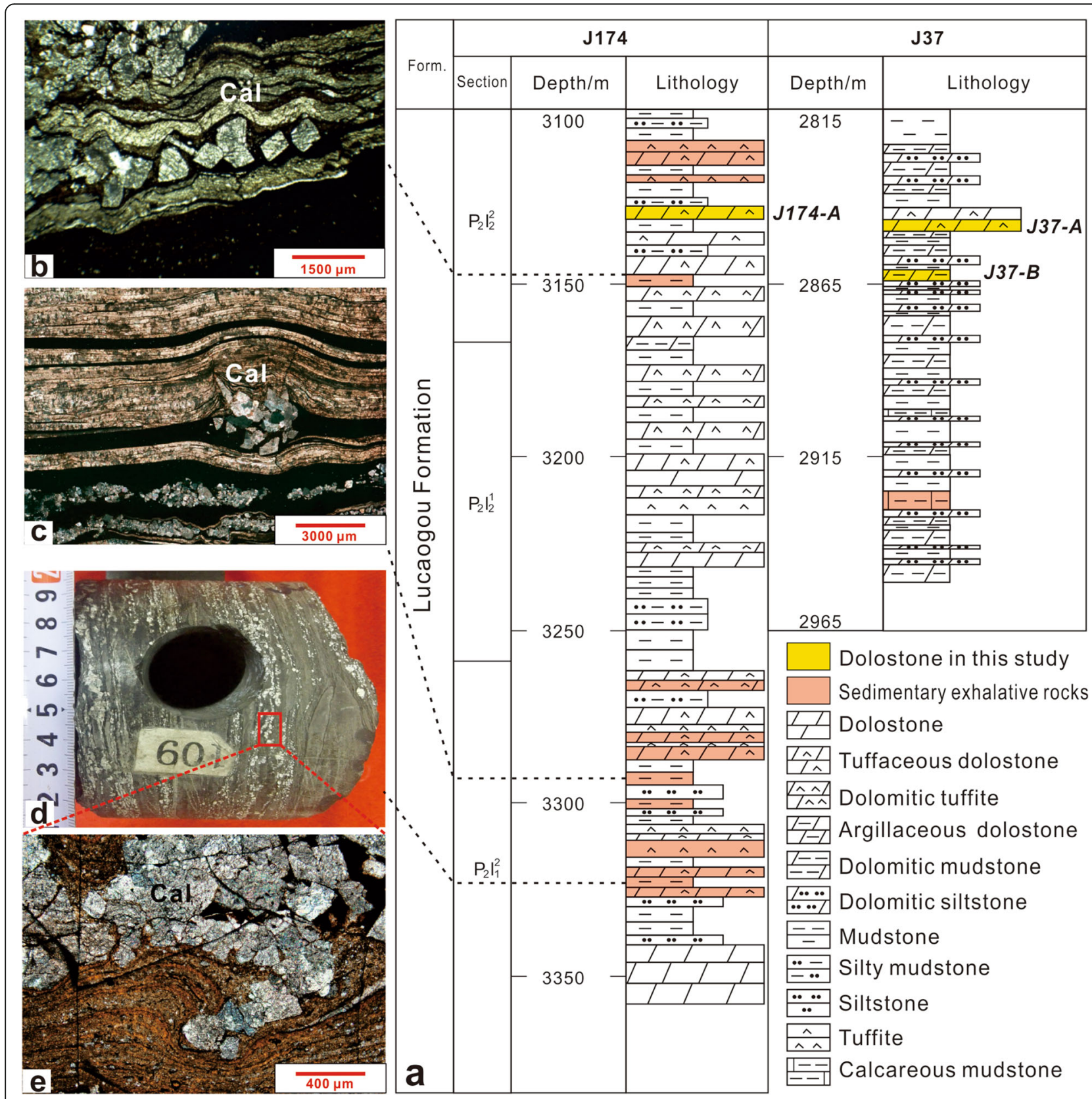

Fig. 2 Distributions of sedimentary exhalative rocks (according to Liu et al. 2019) and dolostones of the Middle Permian Lucaogou Formation in Well J174 and Well $J 37$ (a), and petrographic characteristics of the sedimentary exhalative rocks in Well J174 (b-e). a Lithostratigraphy of the Lucaogou Formation; b Thin-section photomicrograph showing that calcite layers with smooth boundaries are deformed around rigid calcite crystals under cross-polarized light; c Thin-section photomicrograph of calcite layers and calcite crystals; d Photograph of a sedimentary exhalative rocks with coarse-grained calcites scattered in fine-grained matrix; e Thin-section photomicrograph showing fractured calcite crystals in the rectangle part in (d) under plane-polarized light. Zonal structures are present in the crystal

broken calcite breccia clasts scattered in a matrix and intact calcite layers. Syn-sedimentary deformation structures are widely distributed in the surrounding matrix (Fig. 2b-e). The homogenization temperature values of fluid inclusions in the calcites range from $134.7^{\circ} \mathrm{C}$ to $400{ }^{\circ} \mathrm{C}$ ( $\mathrm{Li}$ et al. 2017a). It is inferred that the calcite crystals in the breccia crystallized from upward- migrating hydrothermal fluids and then settled to the lake bottom after an intense explosive eruption, while the calcite layers were formed by quiet overflow eruptions (Li et al. 2017a; Liu et al. 2018).

The dolostones in this study mainly distribute in the upper section of the Lucaogou Formation, formed in a late stage of hydrothermal activity. 
Table 2 Mineral compositions and contents of the selected dolostones in the Middle Permian Lucaogou Formation in Jimusar Sag, eastern Junggar Basin

\begin{tabular}{|c|c|c|c|c|c|c|c|}
\hline & J37-A & & & J37-B & J174-A & & \\
\hline & $\begin{array}{l}\text { Upper part sampled } \\
\text { by a micro-drill }\end{array}$ & $\begin{array}{l}\text { Lower part sampled } \\
\text { by a micro-drill }\end{array}$ & Bulk $^{\mathrm{b}}$ & Bulk $^{\mathrm{a}}$ & $\begin{array}{l}\text { Upper part sampled by a } \\
\text { micro-drill }\end{array}$ & $\begin{array}{l}\text { Lower part sampled } \\
\text { by a micro-drill }\end{array}$ & Bulk \\
\hline $\begin{array}{l}\text { Dolomite } \\
\text { (ferriferous) }\end{array}$ & $72.80 \%$ & $17.40 \%$ & $52.00 \%$ & $58.90 \%$ & $68.00 \%$ & $26.20 \%$ & $50.00 \%$ \\
\hline Albite & $6.80 \%$ & $23.80 \%$ & $12.00 \%$ & & $18.10 \%$ & $27.70 \%$ & $23.00 \%$ \\
\hline $\begin{array}{l}\text { Potassium } \\
\text { feldspar }\end{array}$ & $8.20 \%$ & $20.50 \%$ & $12.00 \%$ & & & & \\
\hline Buddingtonite & & & & & $5.40 \%$ & $37.40 \%$ & $20.00 \%$ \\
\hline Analcime & & $18.60 \%$ & $10.00 \%$ & & & & \\
\hline Quartz & $12.20 \%$ & $17.70 \%$ & $14.00 \%$ & & $8.40 \%$ & $3.90 \%$ & $5.00 \%$ \\
\hline $\begin{array}{l}\text { Quartz } \\
\text { (chalcedony) }\end{array}$ & & & & $41.10 \%$ & & & \\
\hline Calcite & & & & & & $4.80 \%$ & $2.00 \%$ \\
\hline Illite & & $2.00 \%$ & trace & & & & \\
\hline Biotite & & & trace & & & & \\
\hline Rock naming & Analcime-feldspar do & lostone (AFD) & & $\begin{array}{l}\text { Silicic dolostone } \\
\text { (SD) }\end{array}$ & Buddingtonite-albite dolos & e (BAD) & \\
\hline
\end{tabular}

analyzed by XRD. The upper and lower parts denote the corresponding parts of the dolostone samples in Figs. 3e, 4a and 5a

${ }^{b}$ estimated based on thin section observation and electron probe microanalysis

\subsection{Petrological and mineralogical characteristics of dolostones}

The mineral compositions and contents of the selected dolostones in the Middle Permian Lucaogou Formation are shown in Table 2.

\subsubsection{Dolostone J37-A}

Dolostone J37-A is composed of a lower layer of analcime-feldspar-dolomite lens and an upper dolomite layer (Fig. 3e), between which is a thin layer of dark grey tufaceous dolomite (Fig. 3a). The boundary between the sample and the underlying tufaceous dolostone (Fig. 3h) is irregular (Fig. 3g), and syn-sedimentary deformation structure is observed in the lower laminated tufaceous dolostone (Fig. 3e), which indicates that dolostone J37-A formed in the depositional stage of this unit.

The dolostone consists of dolomite, albite, potassium feldspar, analcime, quartz and trace amounts of illite and biotite (Table 2). In the lower analcime-feldspar-dolomite lens, the analcimes exhibit euhedral-subhedral crystals and incomplete extinction under cross-polarized light (Fig. 3a, c-d). The EPMA results indicate that the incomplete extinction is caused by the analcime being partly replaced by potassium feldspar and buddingtonite (Fig. 3i). The analcime is cemented by potassium feldspar, buddingtonite and euhedral platy albite (Fig. 3a, c-d, f, i). Unexpectedly, the buddingtonite was not detected by XRD. Given that these crystals formed by replacing potassium feldspar (see Section 5), we speculate that a relatively low replacement extent (see Table 8) may be responsible or that they were not sampled by the micro-drill for analysis. The dolomite is mainly present as cloddy aggregates encircling analcime-feldspar assemblages (Fig. 3c-d). The dolomite is composed of spherical or sub-spherical micro-crystalline crystals with particle sizes of $5-15 \mu \mathrm{m}$ (Fig. 3f, j). The morphological difference between the spherical dolomite (Fig. 3n) and the rhombic euhedral dolomite in the dolomitic rocks in the Lucaogou Formation (Fig. 3o) is clearly shown in the SEM images.

The upper part is mainly composed of dolomite (Fig. 3b, $\mathrm{j}$ ), in which terrestrial clasts (Fig. 3k) and crystal pyroclasts (Fig. 3l-m) of quartz and feldspar are dispersed. Two peculiar phenomena should be noted. First, buddingtonite is present as annuli on the edges of potassium feldspar cemented by dolomite (Fig. 3k). Second, the albite cemented by dolomite has been replaced by dolomite (Fig. 3l-m), and irregular albite, whose original boundaries (the red dotted line in Fig. 3m) can be distinguished easily in the backscattered images, remains.

In contrast to normal carbonate rocks, the albite, potassium feldspar and analcime in this dolostone show characteristics of chemical precipitation rather than of terrigenous clasts, occurred with syn-sedimentary deformation structures, which reveals a different genesis from normal carbonate rocks. We tentatively named the dolostone J37-A as analcime-feldspar dolostone (AFD).

\subsubsection{Dolostone J37-B}

Dolostone J37-B is composed of dark grey dense finegrained rock (Fig. 4a); and is composed of only dolomite and chalcedony (Table 2). The dolomite crystals are black grey spherulites under plane-polarized light and 


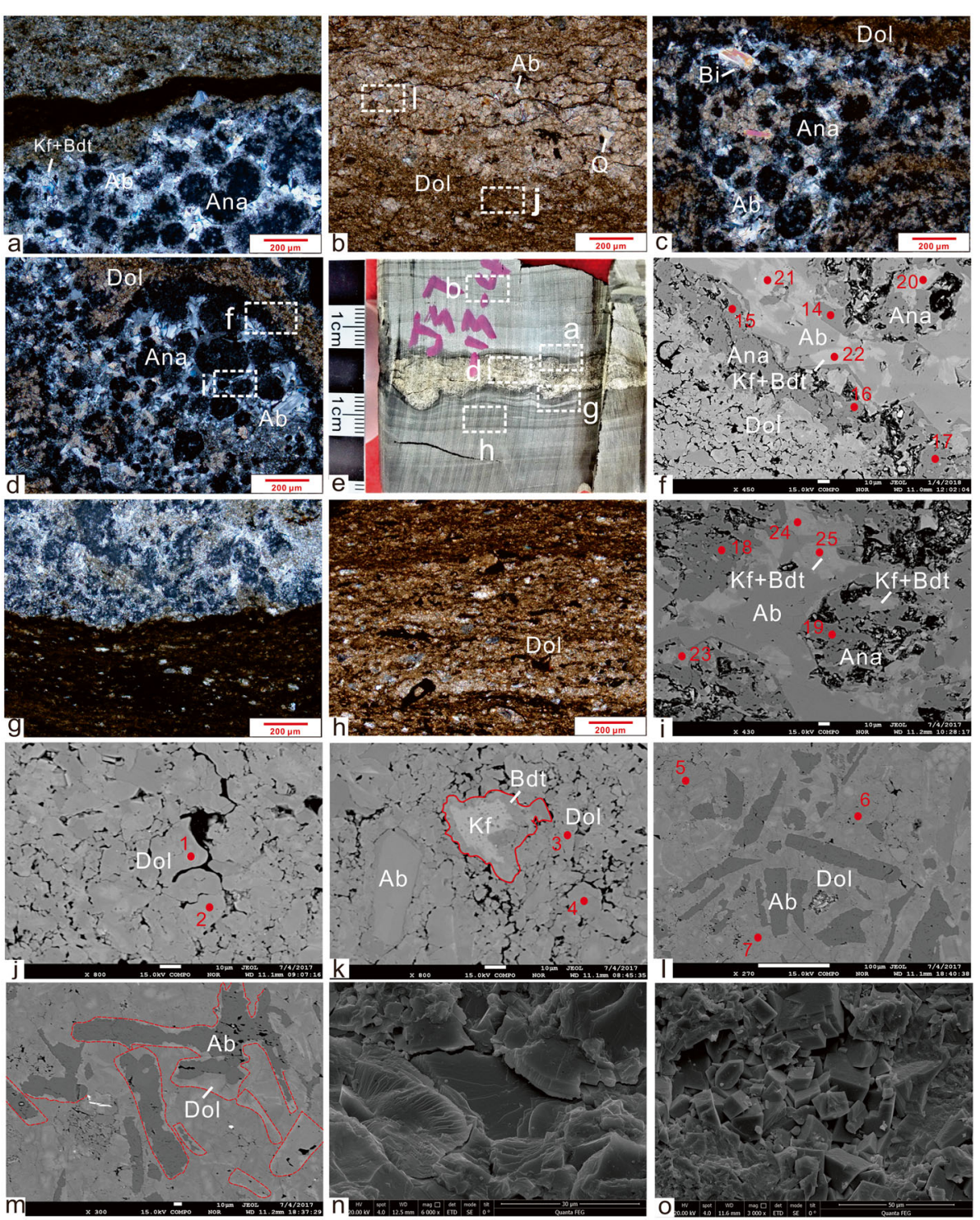

Fig. 3 Typical photographs of the analcime-feldspar dolostone (AFD) of the Middle Permian Lucaogou Formation in Well J37 at 2849.3 m, Jimusar Sag, Junggar Basin. a Thin-section photomicrograph of the thin layer of dark gray tufaceous dolomite in the AFD under cross-polarized light; $\mathbf{b}$ Thin-section photomicrograph of the upper part of the AFD under cross-polarized light; $\mathbf{c}$ Thin-section photomicrograph showing the dolomites in the AFD crystallizing in the intergranular space of analcimes and albites, or exhibiting as banded and amorphous aggregations under crosspolarized light; d Thin-section photomicrograph showing the dolomite aggregations in the AFD encircle analcimes and albites under crosspolarized light; e Photograph of the AFD and the below tufaceous dolostone; $\mathbf{f}$ Back-scattering image of the area "f" in (d) showing the spherical and aciniform dolomites coexisting with analcimes, albites, potassium feldspars and buddingtonites; $\mathbf{g}$ Thin-section photomicrograph of the boundary between the AFD and the below tufaceous dolostone under cross-polarized light; $\mathbf{h}$ Thin-section photomicrograph of the area " $\mathbf{h}$ " in (e) showing the tufaceous dolostone under cross-polarized light; $\mathbf{i}$ Back-scattering image of the area "i" in (d) showing the analcimes and the intergrowth of potassium feldspars and buddingtonites within the analcimes; $\mathbf{j}$ Back-scattering image of the area "j $\mathbf{j}$ " in (b) showing the upper part of the AFD; $\mathbf{k}$ Back-scattering image of the upper part of the AFD showing a potassium feldspar cemented by dolomites was replaced by buddingtonite in the edge; I Back-scattering image of the area "I" in (b) showing albite crystal pyroclasts were cemented and replaced by dolomites in the upper part of the AFD; $\mathbf{m}$ Back-scattering image of the replacement of albites by dolomites; $\mathbf{n}$ Scanning electron microscope image of micro-powder xenomorphic dolomites in the analcime-albite dolostone; o Scanning electron microscope image of euhedral dolomites taken from Well $J 37$ at $2883.5 \mathrm{~m}$. The red points represent the electronic probe analysis locations. Ab=Albite; Ana $=A n a l c i m e ; ~ B d t=$ Buddingtonite; $\mathrm{Bi}=$ Biotite; Dol = Dolomite; $\mathrm{Kf}=$ Potassium feldspar; $\mathrm{Q}=$ Quartz 

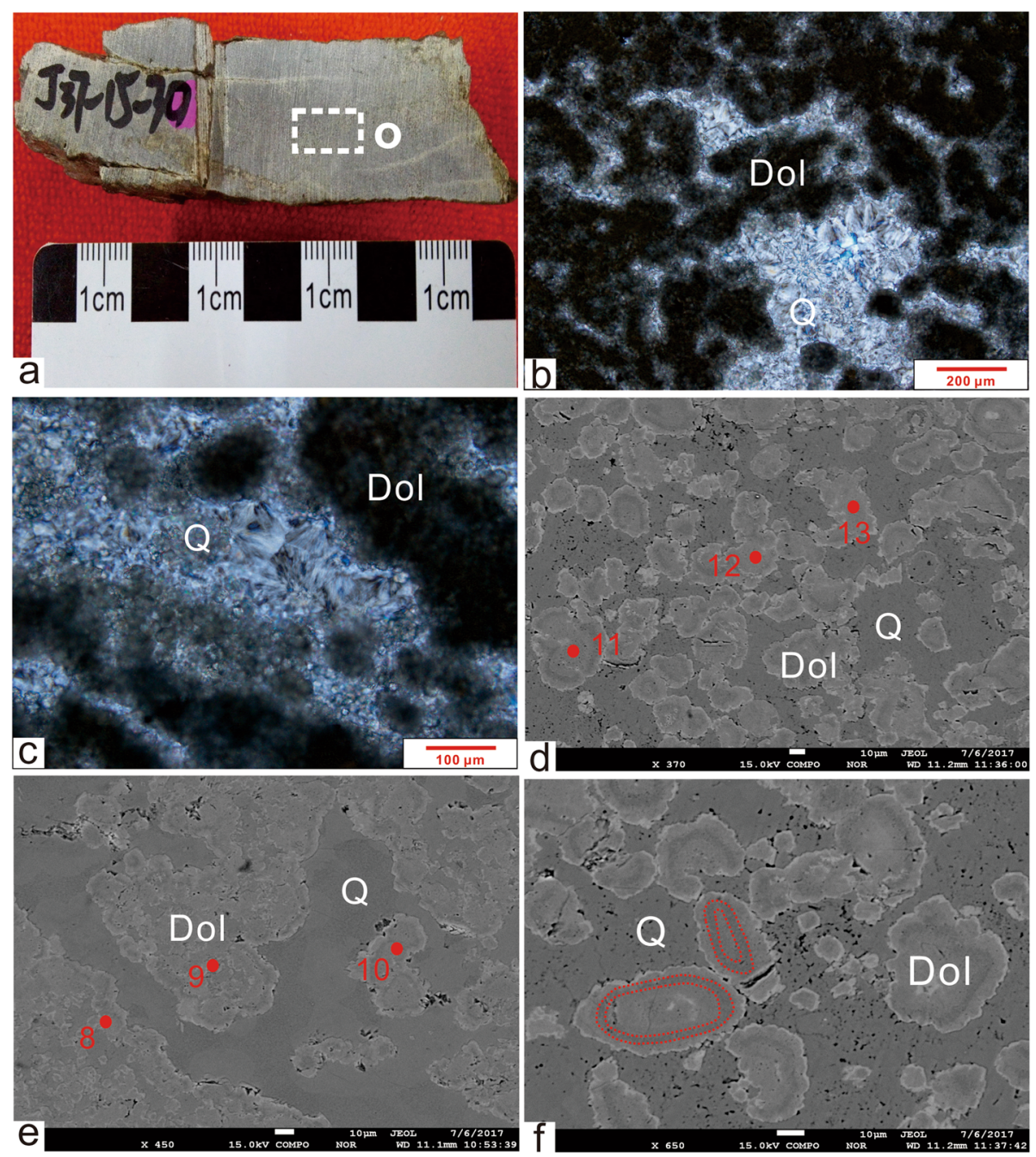

Fig. 4 Typical photographs of the silicic dolostone (SD) of the Middle Permian Lucaogou Formation in Well J37 at 2863.6 m, Jimusar Sag, Junggar Basin. a Photograph of the SD; $\mathbf{b}$ Thin-section photomicrograph showing the brown dolomite spherulites (Dol), between which are chalcedony $(\mathrm{Q})$, in the SD under cross-polarized light; $\mathbf{c}$ Thin-section photomicrograph of the SD under cross-polarized light; $\mathbf{d}$ Back-scattering image of the SD; e Back-scattering image of the SD; $\mathbf{f}$ Back-scattering image showing the dolomite spherulites in which zonal structure develops due to varying iron content. The red points represent the electronic probe analysis locations. Dol= Dolomite; $Q=Q u a r t z$

have grain sizes of $10-50 \mu \mathrm{m}$ (Fig. 4d-f). The FeO contents of the dolomite spherulites increase and then decrease from the grain margin inward, resulting in a zonal structure in the backscattered images. The chalcedony is present between the dolomite spherulites (Fig. 4b-c). We tentatively named the dolostone J37-B as silicic dolostone (SD).

\subsubsection{Dolostone J174-A}

Dolostone J174-A is also composed of dark grey dense fine-grained rock (Fig. 5a), consisting of dolomite, albite, buddingtonite, quartz and trace amounts of calcite (Table 2). The dolomite content decreases and the buddingtonite content increases with increasing depth. The dolomite is composed of spherulites or irregular xenomorphic particles with grain sizes less than $10 \mu \mathrm{m}$, and the dolomite particles have been cemented by albite. The backscattered images indicate lower $\mathrm{FeO}$ content in the mineral cores than in the edges of the dolomite grains (Fig. 5e). Authigenic euhedral platy albite grains can be found (Fig. 5g-h). Black spherulites are present in the lower part of the sample, and their sizes increase with increasing depth, from $50 \mu \mathrm{m}$ to $200 \mu \mathrm{m}$ (Fig. 5c-d). The normally graded structure reveals sorting and sedimentary processes after spherulite formation. Buddingtonite aggregates were detected by EPMA in the spherulites, and the remaining parts were holes, which made the spherulites black under the polarizing microscope. Between the spherulites, dolomite microcrystals were cemented by albite (Fig. 5f). 

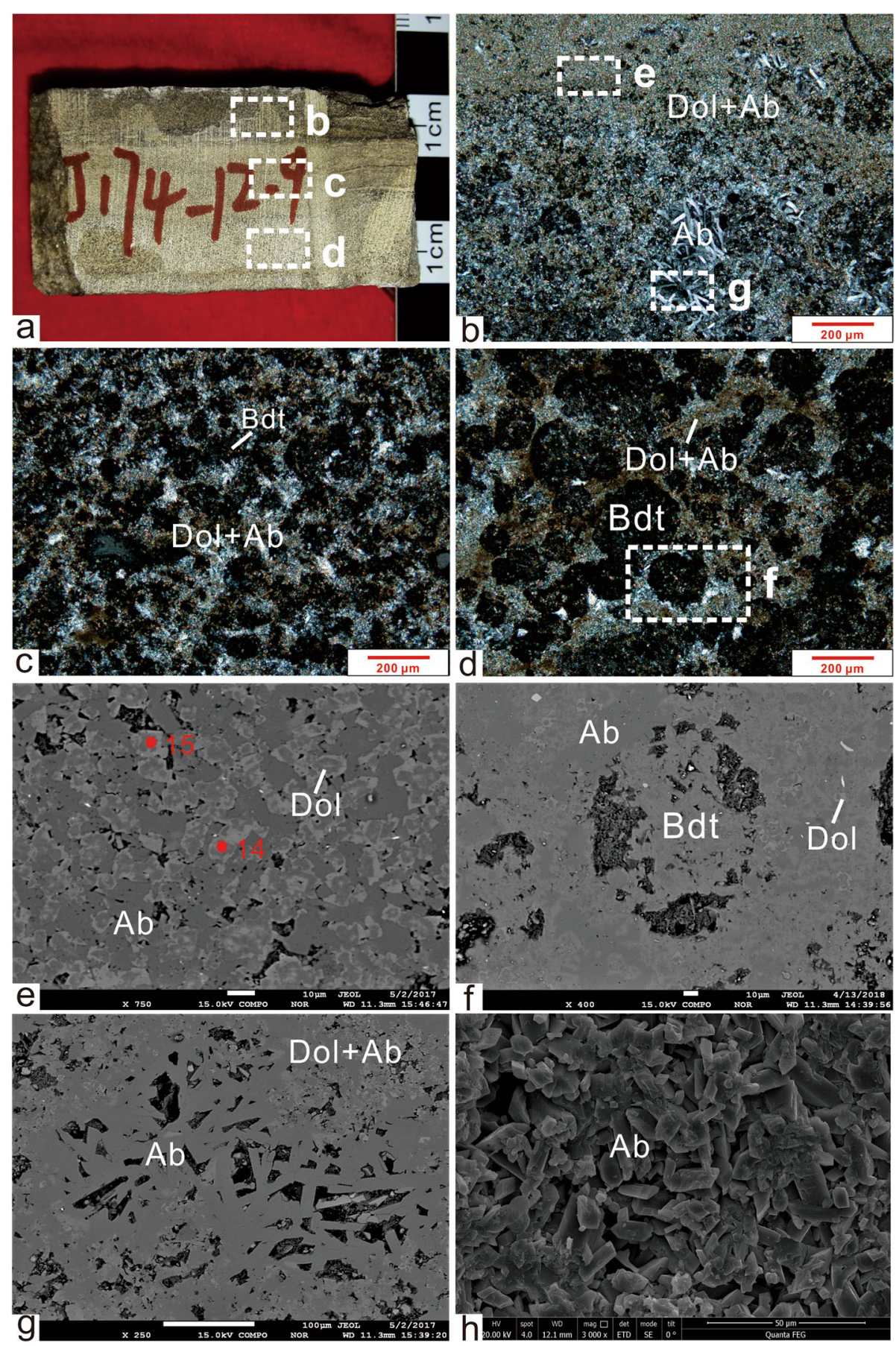

Fig. 5 Typical photographs of the buddingtonite-albite dolostone (BAD) of the Middle Permian Lucaogou Formation in Well $\mathbf{J 1 7 4}$ at $3126.5 \mathrm{~m}$, Jimusar Sag, Junggar Basin. a Photograph of the BAD; $\mathbf{b}$ Thin-section photomicrograph of the BAD consisting of dolomite microlites and albites, in which authigene lath-shaped albites present, under cross-polarized light; c Thin-section photomicrograph of the dolomitic-albite buddingtonite rock, in which dolomites and albites filled the holes between black spherulites under cross-polarized light; $\mathbf{d}$ Thin-section photomicrograph of the lower part of the dolomitic-albite buddingtonite rock, in which black spherulites are bigger, under cross-polarized light; e Back-scattering image showing the dolomite spherulites being cemented by albites; $\mathbf{f}$ Back-scattering image of black spherulites consisting of buddingtonites and holes, between which are dolomites and albites; $\mathbf{g}$ Back-scattering image of authigene lath-shaped albites; $\mathbf{h}$ Scanning electron microscope image of the authigenic albites. The red points in e represent the electronic probe analysis locations. Ab = Albite; Bdt=Buddingtonite; Dol=Dolomite 
Given the presence of buddingtonite and authigenic albite, two representative hydrothermal minerals (see Section 5), and the characteristics of chemical precipitation, we speculate that this dolostone formed in a different way compared to normal carbonates. And we tentatively named the dolostone J174-A as buddingtonite-albite dolostone (BAD).

\subsubsection{Mineral elements and degree of order of dolomites}

The EPMA results of dolomites are shown in Table 3. It is obvious that the substitution of iron and manganese ions for magnesium ions and the substitution of strontium ions for calcium ions are common in the dolomites. The dolomite in the AFD has lower contents of $(\mathrm{CaO}+\mathrm{SrO})$ (with an average of $28.946 \%)$ and higher contents of $(\mathrm{MgO}+\mathrm{TFeO}+\mathrm{MnO})$ (with an average of $22.577 \%$ ) than ideal dolomite, whose $\mathrm{CaO}$ and $\mathrm{MgO}$ contents are $30.41 \%$ and $21.86 \%$, respectively, while the dolomite in the SD has a larger $(\mathrm{CaO}+\mathrm{SrO})$ value (with an average of $31.034 \%)$ and a less $(\mathrm{MgO}+\mathrm{TFeO}+\mathrm{MnO})$ value (with an average of $20.752 \%$ ). The composition of the dolomite in the BAD is similar to that of ideal dolomite. All dolomites in three types of dolostone have order of degree to some extent, and the dolomite in the BAD has the lowest degree of order (Table 4). Given their ordered nature, all of them are proper dolomite despite some degree of stoichiometric deviation (Gregg et al. 2015), and they are considered as proto-dolomites (Gaines 1977).

All the dolomite types are rich in iron ions, and both the AFD and the BAD are dominated by ferriferous dolomite (with a TFeO content greater than 1.55\%; Tucker and Wright 1990).

\subsection{Geochemical characteristics}

\subsubsection{Strontium isotopic compositions}

The strontium isotopic compositions of the AFD, SD, BAD, and euhedral-subhedral micro-crystalline dolostone were obtained. The results are shown in Table 5 and Fig. 6.

The ${ }^{87} \mathrm{Sr} /{ }^{86} \mathrm{Sr}$ values of all four types of dolostone (referring to seven black dots in Fig. 6), which plot between the ${ }^{87} \mathrm{Sr} /{ }^{86} \mathrm{Sr}$ values of crustal source sialic rocks $(0.720 \pm 0.005$; Faure 1986) and mantle source (0.70350; Palmer and Elderfield 1985), are closer to those of the Permian mantle-derived hydrothermal-sedimentary dolomites in the Santanghu Basin, Xinjiang, NW China (with an average of 0.705005; Liu et al. 2012) than those of the Permian seawater (0.70685-0.70800; Korte et al. 2006). In addition, they are much lower than the ${ }^{87} \mathrm{Sr} /{ }^{86} \mathrm{Sr}$ values of the Cretaceous hydrothermalsedimentary dolomites in the Jiuquan Basin (with an average of 0.714718; Wen et al. 2013).

Table 3 Electron microprobe data of chemical composition (\%) of dolomites in the Middle Permian Lucaogou Formation in Jimusar Sag, eastern Junggar Basin

\begin{tabular}{|c|c|c|c|c|c|c|c|c|c|c|c|c|c|c|}
\hline Mineral & Analysis location & $\mathrm{Na}_{2} \mathrm{O}$ & $\mathrm{MgO}$ & $\mathrm{Al}_{2} \mathrm{O}_{3}$ & $\mathrm{SiO}_{2}$ & $\mathrm{SrO}$ & $\mathrm{CaO}$ & $\mathrm{K}_{2} \mathrm{O}$ & $\mathrm{MnO}$ & TFeO & $\mathrm{BaO}$ & Total & $\mathrm{CaO}+\mathrm{SrO}$ & $\mathrm{MgO}+\mathrm{TFeO}+\mathrm{MnO}$ \\
\hline \multirow{8}{*}{$\begin{array}{l}\text { Dolomites in } \\
\text { the AFD }\end{array}$} & 1 & 0.227 & 21.884 & 0.032 & 0.000 & 0.217 & 28.416 & 0.040 & 0.373 & 1.779 & 0.018 & 52.986 & 28.633 & 24.036 \\
\hline & 2 & 0.121 & 20.064 & 0.147 & 0.085 & 0.510 & 29.832 & 0.062 & 0.304 & 0.659 & 0.208 & 51.992 & 30.342 & 21.027 \\
\hline & 3 & 0.107 & 18.798 & 0.012 & 0.202 & 0.394 & 27.896 & 0.046 & 0.158 & 3.257 & 0.206 & 51.076 & 28.290 & 22.213 \\
\hline & 4 & 0.198 & 22.139 & 0.024 & 0.000 & 1.052 & 29.197 & 0.001 & 0.127 & 0.827 & 0.154 & 53.719 & 30.249 & 23.093 \\
\hline & 5 & 0.309 & 20.054 & 0.093 & 0.079 & 0.179 & 27.392 & 0.029 & 0.129 & 2.643 & 0.009 & 50.916 & 27.571 & 22.826 \\
\hline & 6 & 0.136 & 20.137 & 0.008 & 0.000 & 0.752 & 28.193 & 0.000 & 0.404 & 1.653 & 0.009 & 51.292 & 28.945 & 22.194 \\
\hline & 7 & 0.189 & 20.885 & 0.023 & 0.000 & 0.167 & 28.426 & 0.000 & 0.013 & 1.752 & 0.000 & 51.455 & 28.593 & 22.650 \\
\hline & Average & 0.184 & 20.566 & 0.048 & 0.052 & 0.467 & 28.479 & 0.025 & 0.215 & 1.796 & 0.086 & 51.919 & 28.946 & 22.577 \\
\hline \multirow{7}{*}{$\begin{array}{l}\text { Dolomites in } \\
\text { the SD }\end{array}$} & 8 & 0.349 & 20.524 & 0.000 & 0.002 & 0.197 & 32.079 & 0.000 & 0.000 & 0.220 & 0.064 & 53.435 & 32.276 & 20.744 \\
\hline & 9 & 0.120 & 19.773 & 0.009 & 0.024 & 0.135 & 30.482 & 0.016 & 0.000 & 0.901 & 0.100 & 51.560 & 30.617 & 20.674 \\
\hline & 10 & 0.175 & 20.557 & 0.000 & 0.023 & 0.188 & 31.511 & 0.000 & 0.096 & 0.836 & 0.000 & 53.386 & 31.699 & 21.489 \\
\hline & 11 & 0.182 & 18.915 & 0.067 & 0.000 & 0.190 & 31.491 & 0.000 & 0.089 & 0.636 & 0.018 & 51.588 & 31.681 & 19.640 \\
\hline & 12 & 0.120 & 18.473 & 0.033 & 0.000 & 0.277 & 28.761 & 0.000 & 0.126 & 3.509 & 0.081 & 51.380 & 29.038 & 22.108 \\
\hline & 13 & 0.328 & 19.262 & 0.017 & 0.000 & 0.108 & 30.783 & 0.005 & 0.019 & 0.576 & 0.144 & 51.242 & 30.891 & 19.857 \\
\hline & Average & 0.212 & 19.584 & 0.021 & 0.008 & 0.183 & 30.851 & 0.004 & 0.055 & 1.113 & 0.068 & 52.099 & 31.034 & 20.752 \\
\hline \multirow{5}{*}{$\begin{array}{l}\text { Dolomites in } \\
\text { the BAD }\end{array}$} & 14 & 0.113 & 17.852 & 0.012 & 0.000 & 0.224 & 31.964 & 0.006 & 0.082 & 3.038 & 0.036 & 53.327 & 32.188 & 20.972 \\
\hline & 15 & 0.141 & 16.909 & 0.000 & 0.019 & 0.276 & 29.788 & 0.000 & 0.083 & 4.113 & 0.072 & 51.401 & 30.064 & 21.105 \\
\hline & & 0.158 & 18.558 & 0.007 & 0.007 & 0.207 & 30.083 & 0.008 & 0.083 & 3.729 & 0.144 & 52.984 & 30.290 & 22.370 \\
\hline & & 0.092 & 18.067 & 0.000 & 0.025 & 0.171 & 30.683 & 0.009 & 0.172 & 3.915 & 0.216 & 53.350 & 30.854 & 22.154 \\
\hline & Average & 0.126 & 17.847 & 0.005 & 0.013 & 0.220 & 30.630 & 0.006 & 0.105 & 3.699 & 0.117 & 52.766 & 30.850 & 21.650 \\
\hline
\end{tabular}


Table 4 Degree of order of the dolomites in the Middle Permian Lucaogou Formation in Jimusar Sag, eastern Junggar Basin

\begin{tabular}{llll}
\hline & Dolomites in the AFD & Dolomites in the SD & Dolomites in the BAD \\
\hline Molarity of $\mathrm{MgCO}_{3}(\mathrm{~mol} \%)$ & $49.97 \%$ & $47.10 \%$ & $47.57 \%$ \\
Degree of order & 0.60 & 0.40 & 0.17
\end{tabular}

\subsubsection{Carbon and oxygen isotopes}

The results of carbon and oxygen isotope analysis are shown in Table 6 and Fig. 7. Dolomites in this study have positive $\delta^{13} C_{\mathrm{PDB}}$ and negative $\delta^{18} \mathrm{O}_{\mathrm{PDB}}$ values, similar to those of the two representative hydrothermal-sedimentary dolostones in China, the Cretaceous dolostones in the Jiuquan Basin (Wen et al. 2013) and the Permian dolostones in the Santanghu Basin (Liu et al. 2012; Jiao 2017). The $\delta^{18} \mathrm{O}_{\mathrm{PDB}}$ values of the studied dolostones are in the same range as those of the hydrothermal dolostones in the Jiuquan Basin, in Sardinia in Italy (Boni et al. 2000), and in the Western Canada Sedimentary Basin (Al-Aasm 2003).

\section{Discussion}

Three critical characteristics of the dolostones in this study can be outlined. First, the paragenetic relationship of dolomite with analcime, albite, buddingtonite and chalcedony and the associated evidence for chemical precipitation reveal that the genesis of these dolostones differs from that of normal carbonates. Second, the dolomite is present as micro-sized spherical particles that are similar to the dolomite precipitating directly from solution at high temperatures in the laboratory (RodriguezBlanco et al. 2015). Third, the replacement of albite by dolomite in the upper part of the AFD (Fig. 3l, m) indicates exceptionally high temperatures (e.g., $>400{ }^{\circ} \mathrm{C}$; Nishiyama 1990). We argue that the dolostones are of hydrothermal genesis based on the above facts. The formation stage of the dolostones, the genesis of the paragenetic minerals, the geochemical characteristics of the dolostones, the nature of the ore-forming fluid, and the dolomite formation mechanisms are discussed below.

\subsection{Formation stage}

As previously mentioned, the syn-sedimentary deformation below the AFD indicates that the AFD formed syn-depositionally. We suggest that the SD and BAD in this study are syn-depositional deposits as well because (1) the dolomite grains in the form of micro-sized spherical particles differ from the larger euhedral dolomite grains that form during a diagenetic stage or saddle dolomite grains that form through hydrothermal replacement (e.g., Luczaj et al. 2006); (2) their macro-scale appearances are homogeneous, and no replacement texture or metasomatic relict texture can be found; (3) the sorting and sedimentary processes revealed by the normally graded structure in the BAD could hardly have occurred in a diagenetic environment; (4) the degree of order in the Permian lacustrine dolomites in the Urumchi area, southwest of the study area, does not vary with depth, i.e., the dolomites were not affected by diagenesis (Li et al. 2017b), which suggests that dolomites formed by diagenetic replacement are hardly present in this area. A similar case was also reported in Santanghu Basin, an adjacent basin situated to the east of the Junggar Basin (Jiao 2017).

\subsection{Paragenetic minerals}

Among the paragenetic minerals associated with dolomite in this study, analcime (Zheng et al. 2003; Liu et al. 2010, 2012; Wen et al. 2013), albite (Zheng et al. 2003; Liu et al. 2010; Zhang et al. 2010) and chalcedony (Tao et al. 2016) have all been reported in hydrothermalsedimentary rock studies. Given the diverse genetic types of analcime and scarce reports of buddingtonite, these two minerals are analysed further.

By conducting simulation experiments and theoretical calculations, Coombs and Whetten (1967) divided the analcime in sedimentary rocks into three groups: silicarich analcime (approximately $\mathrm{Na}_{13} \mathrm{Al}_{13} \mathrm{Si}_{35} \mathrm{O}_{96} \cdot \mathrm{nH}_{2} \mathrm{O}-$ $\mathrm{Na}_{14} \mathrm{Al}_{14} \mathrm{Si}_{34} \mathrm{O}_{96} \cdot \mathrm{nH}_{2} \mathrm{O}$ ) formed by alteration of siliceous volcanic glass by alkaline fluid; middle-silica analcime (approximately $\mathrm{Na}_{14} \mathrm{Al}_{14} \mathrm{Si}_{34} \mathrm{O}_{96} \cdot \mathrm{nH}_{2} \mathrm{O}$ ) formed by replacement under burial conditions; and, silica-poor analcime $\left(\mathrm{Na}_{15} \mathrm{Al}_{15} \mathrm{Si}_{33} \mathrm{O}_{96} \cdot \mathrm{nH}_{2} \mathrm{O}-\mathrm{Na}_{16} \mathrm{Al}_{16} \mathrm{Si}_{32} \mathrm{O}_{96} \cdot \mathrm{nH}_{2} \mathrm{O}\right)$ directly precipitating from highly alkaline water and coexisting with chemically precipitated dolomite. The $\mathrm{Si} /$ $\mathrm{Al}$ values of the analcime in the AFD range from 2.153 to 2.494 (Table 7), mainly falling within the region of silica-poor analcime (Fig. 8). Their coexistence with dolomite is also consistent with the characteristics of silica-poor analcime. The euhedral-subhedral crystals of

Table 5 Strontium isotopic compositions of dolomites in the Middle Permian Lucaogou Formation in Jimusar Sag, eastern Junggar Basin

\begin{tabular}{|c|c|c|c|c|c|c|c|}
\hline \multirow[b]{2}{*}{ Sample number } & \multicolumn{3}{|c|}{ Euhedral-subhedral micro-powder dolostone } & \multicolumn{2}{|l|}{ AFD } & \multirow{2}{*}{$\frac{\mathrm{SD}}{\mathrm{Jm} 37-3}$} & \multirow{2}{*}{$\frac{\mathrm{BAD}}{\mathrm{Jm} 174-\mathrm{A}}$} \\
\hline & Jm174-1 & Jm174-2 & $J \mathrm{~m} 174-3$ & Jm37-1 & Jm37-2 & & \\
\hline${ }^{87} \mathrm{Sr} /{ }^{86} \mathrm{Sr}$ & 0.705742 & 0.705739 & 0.705570 & 0.705504 & 0.705591 & 0.705474 & 0.706177 \\
\hline
\end{tabular}




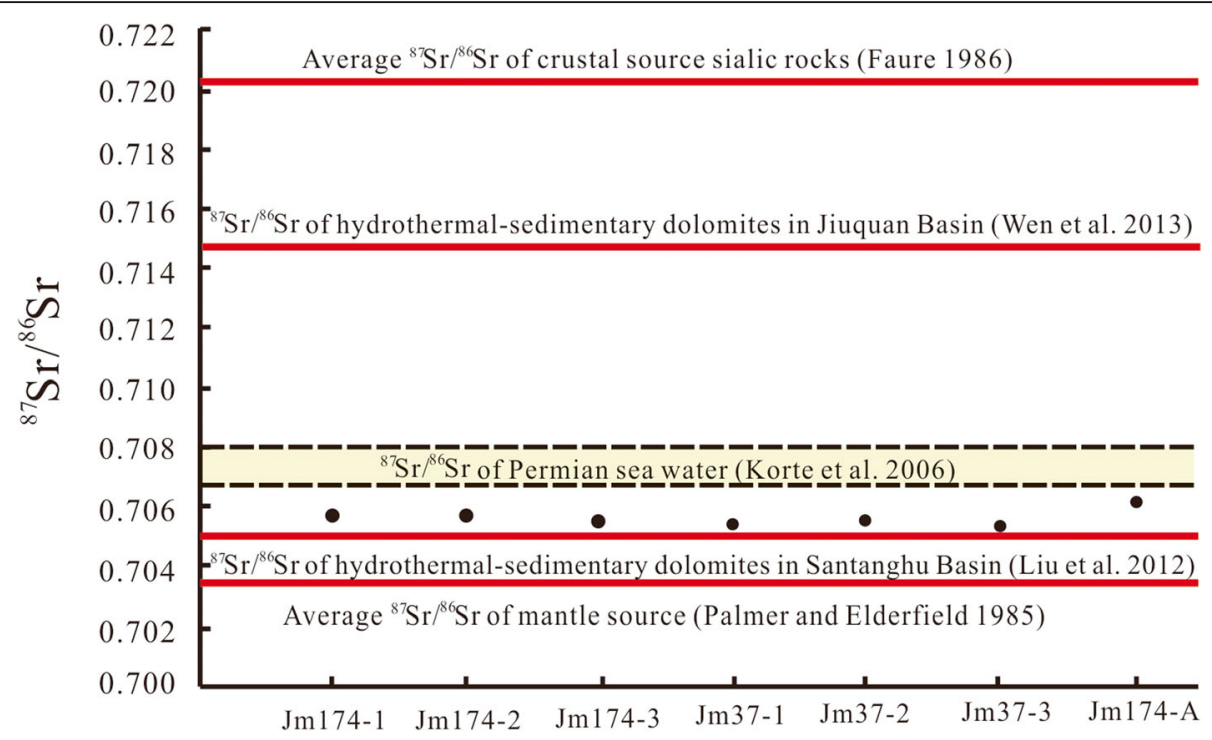

Fig. 6 Characteristics of strontium isotopes of dolomites in the Middle Permian Lucaogou Formation in Jimusar Sag, eastern Junggar Basin

analcime in the AFD are different from the cement occurrence of the middle-silica analcime. Furthermore, quartz or other siliceous minerals, generally coexisting with silica-rich analcime, are absent in the AFD. Therefore, the analcime in the AFD is silica-poor analcime and precipitated directly from highly alkaline water.

Buddingtonite (with a theoretical molecular formula of $\left.\left(\mathrm{NH}_{4}\right)\left[\mathrm{AlSi}_{3} \mathrm{O}_{8}\right]\right)$ formed through the replacement of potassium ions in potassium feldspars with ammonium ions, is generally present in hot springs (Barker 1964; Erd et al. 1964; Krohn 1987; Krohn et al. 1993) and is recognized as an indicator mineral of hydrothermal activity (Pampeyan 2010). In a few cases, it has been found in diagenetic environments, as authigenic edges on feldspar and as microfracture fill (Hori 1986; Ramseyer et al. 1993). The buddingtonite in this study resembles potassium feldspar, and no authigenic buddingtonite edges were found. Furthermore, the buddingtonite grains are distributed unevenly in limited areas; the contents reach up to $40 \%$ in several samples. In contrast, the buddingtonite formed by diagenesis is expected to be distributed relatively evenly in the strata. Therefore, we argue that the buddingtonite in this study (Table 8) is the product of hydrothermal activity. When the hydrothermal fluid rose through organic-rich strata, thermal decomposition of organic matter occurred, and ammonium ions were released into the fluid. When this fluid with abundant ammonium ions erupted at the lake bottom and encountered potassium feldspar crystals, substitution of the potassium ions in the potassium feldspar by ammonium ions occurred due to their similar ionic radius, resulting in the formation of the buddingtonite (Hallam and Eugster 1976). In addition, the inner edge of the buddingtonite annulus in the potassium feldspar clasts cemented by dolomites in the upper part of the AFD is irregular (Fig. 3k), in contrast to the authigenic edges of feldspar grains. The best explanation is that ammonium ions permeated into the feldspar and replaced the potassium ions along the edge.

\subsection{Isotopic geochemical characteristics and nature of ore-forming fluid}

Isotopic geochemistry is widely used to investigate the characteristics and sources of ore-forming fluids. The ${ }^{87} \mathrm{Sr} /{ }^{86} \mathrm{Sr}$ values of the dolomite in this study (with an average of 0.705685; Table 5) are close to those of the mantle source and similar to those of the mantle-derived hydrothermal exhalative dolostone in the Santanghu Basin (Fig. 6), which implies that mantle-derived materials involved in the ore-forming fluid. It is noted that the ${ }^{87} \mathrm{Sr} /{ }^{86} \mathrm{Sr}$ values of the AFD, SD, BAD, and euhedralsubhedral micro-crystalline dolostones are indistinguishable. They are also consistent with the ${ }^{87} \mathrm{Sr} /{ }^{86} \mathrm{Sr}$ values of the dolomitic rocks reported by Jiang et al. (2015), Wang et al. (2019) and Yang et al. (2019). We propose two possible sources of mantle-derived materials: (1) mantle-derived hydrothermal fluids may have participated in the ore-forming fluid and contributed mantle materials (Jiang et al. 2015); (2) the palaeolake water itself may have possessed low ${ }^{87} \mathrm{Sr} /{ }^{86} \mathrm{Sr}$ values due to the intracontinental rift setting of the basin (Wang et al. 2019) and played a key role in the dolostone formation, probably by circulating deeply along fractures, being heated by underlying strata or magma chambers and finally erupting into the lake (Li et al. 2017a). However, it is difficult to provide a definite interpretation at present, and further studies are needed. 
Table 6 Carbon and oxygen isotopic compositions of dolomites in the eastern Junggar Basin (this study), Sangtanghu Basin (Jiao 2017), Jiuquan Basin (Wen et al. 2013), southwestern Sardinia of Italy (Boni et al. 2000), and Western Canada Sedimentary Basin (AlAasm 2003)

\begin{tabular}{|c|c|c|c|c|}
\hline Sample number & Lithology & $\delta^{13} C_{P D B}(\% 0)$ & $\delta^{18} \mathrm{O}_{\mathrm{PDB}}(\%)$ & Symbol in Fig. 7 \\
\hline Jm37-1 & \multirow[t]{2}{*}{ AFD } & 6.16 & -8.22 & \multirow[t]{4}{*}{ Red circle } \\
\hline Jm37-2 & & 7.26 & -6.86 & \\
\hline Jm37-3 & SD & 10.16 & -7.59 & \\
\hline$J \mathrm{~m} 174-\mathrm{A}$ & BAD & 4.16 & -9.81 & \\
\hline Jm174-1 & \multirow[t]{3}{*}{ Euhedral-subhedral micro-crystalline dolostone } & 6.66 & -3.19 & \multirow[t]{10}{*}{ Black circle } \\
\hline Jm174-2 & & 9.17 & -4.08 & \\
\hline Jm174-3 & & 7.60 & -2.32 & \\
\hline$J \mathrm{~m} 7-1$ & \multirow[t]{7}{*}{ Penecontemporaneous dolostone (Zhang et al. 2018) } & 8.84 & -6.31 & \\
\hline$J \mathrm{~m} 7-2$ & & 9.54 & -3.36 & \\
\hline$J \mathrm{~m} 7-3$ & & 8.98 & -3.48 & \\
\hline $\mathrm{Jm} 7-4$ & & 7.38 & -7.55 & \\
\hline $\mathrm{Jm} 7-5$ & & 8.06 & -5.61 & \\
\hline Jm7-6 & & 9.39 & -3.16 & \\
\hline Jm7-7 & & 9.68 & -3.56 & \\
\hline N122-2 & \multirow{12}{*}{$\begin{array}{l}\text { Hydrothermal-sedimentary dolostone in Santanghu } \\
\text { Basin (Jiao 2017) }\end{array}$} & 5.6 & -3.4 & \multirow[t]{12}{*}{ Green square } \\
\hline N122-3 & & 6.4 & -4.0 & \\
\hline N122-5 & & 5.2 & -5.2 & \\
\hline N122-11 & & 7.6 & -6.1 & \\
\hline N122-15 & & 9.9 & -3.1 & \\
\hline N122-24 & & 6.4 & -3.7 & \\
\hline M11-1-b & & 5.6 & -16.4 & \\
\hline M11-2 & & 7.1 & -13.7 & \\
\hline M11-3 & & 6.7 & -13.9 & \\
\hline M11-8 & & 5.6 & -17.4 & \\
\hline M3y-1 & & 9.4 & -1.0 & \\
\hline M41-1 & & 7.0 & -2.0 & \\
\hline QXC04 & \multirow{16}{*}{$\begin{array}{l}\text { Hydrothermal-sedimentary dolostone in Jiuquan Basin } \\
\text { (Wen et al. 2013) }\end{array}$} & 4.18 & -11.01 & \multirow[t]{16}{*}{ Yellow triangle } \\
\hline QXC10 & & 2.46 & -9.70 & \\
\hline QXC11 & & 5.67 & -6.68 & \\
\hline QXC12 & & 5.63 & -6.68 & \\
\hline QXC17 & & 3.58 & -7.90 & \\
\hline QXC18 & & 4.90 & -5.89 & \\
\hline QXC19 & & 4.89 & -7.26 & \\
\hline QXC20 & & 4.43 & -8.15 & \\
\hline QXC21 & & 4.69 & -11.38 & \\
\hline QXC25 & & 4.21 & -11.43 & \\
\hline QXC29 & & 3.54 & -12.19 & \\
\hline QXC34 & & 4.12 & -5.92 & \\
\hline QXC36 & & 3.81 & -7.55 & \\
\hline QXC37 & & 3.77 & -11.28 & \\
\hline QXC38 & & 5.78 & -7.33 & \\
\hline QXC42 & & 2.95 & -10.07 & \\
\hline
\end{tabular}


Table 6 Carbon and oxygen isotopic compositions of dolomites in the eastern Junggar Basin (this study), Sangtanghu Basin (Jiao 2017), Jiuquan Basin (Wen et al. 2013), southwestern Sardinia of Italy (Boni et al. 2000), and Western Canada Sedimentary Basin (AlAasm 2003) (Continued)

\begin{tabular}{|c|c|c|c|c|}
\hline Sample number & Lithology & $\delta^{13} C_{P D B}(\%)$ & $\delta^{18} \mathrm{O}_{\mathrm{PDB}}(\% 0)$ & Symbol in Fig. 7 \\
\hline QXC43 & & 3.31 & -10.21 & \\
\hline QXC45 & & 1.79 & -10.22 & \\
\hline QXC46 & & 3.31 & -7.39 & \\
\hline QXC53 & & 2.55 & -13.47 & \\
\hline QXC54 & & 4.17 & -9.75 & \\
\hline QXC56 & & 4.13 & -10.56 & \\
\hline QXC57 & & 5.82 & -11.18 & \\
\hline QXC58 & & 2.19 & -10.99 & \\
\hline QXC59 & & 1.86 & -14.15 & \\
\hline 23 & \multirow{12}{*}{$\begin{array}{l}\text { Hydrothermal dolostone in southwestern Sardinia, } \\
\text { Italy (Boni et al. 2000) }\end{array}$} & 0.96 & -9.5 & \multirow[t]{12}{*}{ Blue star } \\
\hline $24 a$ & & -0.19 & -8.9 & \\
\hline $24 b$ & & 0.41 & -8.9 & \\
\hline $28(n=5)$ & & 0.41 & -8.9 & \\
\hline DG5 & & 0.04 & -9.1 & \\
\hline CP1 & & -1.48 & -7.8 & \\
\hline $\mathrm{CP} 2$ & & -0.75 & -8.0 & \\
\hline 25 & & 0.47 & -9.5 & \\
\hline $26 b$ & & 0.39 & -9.9 & \\
\hline SM1 & & -0.76 & -8.2 & \\
\hline SM2 & & -0.83 & -8.7 & \\
\hline Dolsb2 & & -0.25 & -9.6 & \\
\hline s1 & \multirow{21}{*}{$\begin{array}{l}\text { Hydrothermal dolostone in U. Debolt-Sikanni, Western } \\
\text { Canada Sedimentary Basin (Al-Aasm 2003) }\end{array}$} & 2.78 & -8.60 & \multirow[t]{21}{*}{ Purple diamond } \\
\hline s2 & & 2.73 & -9.62 & \\
\hline s3 & & 2.08 & -9.47 & \\
\hline s4 & & 2.53 & -10.15 & \\
\hline s5 & & 3.43 & -8.47 & \\
\hline s6 & & 3.00 & -9.50 & \\
\hline s7 & & 2.36 & -8.83 & \\
\hline s8 & & 2.72 & -8.44 & \\
\hline s9 & & 2.83 & -8.60 & \\
\hline s10 & & 2.53 & -8.55 & \\
\hline s11 & & 2.51 & -9.34 & \\
\hline s12 & & 3.30 & -9.27 & \\
\hline s13 & & 1.13 & -8.30 & \\
\hline s14 & & 2.71 & -8.38 & \\
\hline s15 & & 1.38 & -9.85 & \\
\hline s16 & & 2.50 & -9.52 & \\
\hline s17 & & 3.75 & -8.72 & \\
\hline s18 & & 1.81 & -9.28 & \\
\hline s19 & & 2.24 & -9.71 & \\
\hline$s 20$ & & 2.79 & -9.31 & \\
\hline$s 21$ & & 2.91 & -8.14 & \\
\hline
\end{tabular}


Table 6 Carbon and oxygen isotopic compositions of dolomites in the eastern Junggar Basin (this study), Sangtanghu Basin (Jiao 2017), Jiuquan Basin (Wen et al. 2013), southwestern Sardinia of Italy (Boni et al. 2000), and Western Canada Sedimentary Basin (AlAasm 2003) (Continued)

\begin{tabular}{|c|c|c|c|c|}
\hline Sample number & Lithology & $\delta^{13} C_{P D B}(\%)$ & $\delta^{18} \mathrm{O}_{\mathrm{PDB}}(\%)$ & Symbol in Fig. 7 \\
\hline $32-1-S D$ & & 1.80 & -9.81 & \\
\hline $32-1-S D$ & & 1.90 & -10.8 & \\
\hline $32-2-S D$ & & 2.44 & -9.71 & \\
\hline $32-2-S D$ & & 2.53 & -8.78 & \\
\hline $32-10-S D$ & & 1.67 & -9.85 & \\
\hline $32-10-S D$ & & 2.08 & -9.47 & \\
\hline $32-6-S D$ & & 2.56 & -9.42 & \\
\hline $32-6-S D$ & & 2.73 & -9.62 & \\
\hline $32-5-S D$ & & 2.32 & -9.40 & \\
\hline $32-3-S D$ & & 2.49 & -8.80 & \\
\hline $32-3-S D$ & & 2.60 & -8.95 & \\
\hline $32-9-S D$ & & 2.62 & -9.07 & \\
\hline $32-9-S D$ & & 1.54 & -9.47 & \\
\hline 14-3-SD & & 1.48 & -8.17 & \\
\hline 46-19-SD & & 3.00 & -7.95 & \\
\hline 46-19-SD & & 2.80 & -8.88 & \\
\hline $46-20-S D$ & & 3.07 & -7.82 & \\
\hline $46-20-S D$ & & 3.05 & -8.27 & \\
\hline
\end{tabular}

The $\delta^{13} \mathrm{C}$ and $\delta^{18} \mathrm{O}$ values of the dolostones and dolomitic rocks in this study show poor correlations (Fig. 7), indicating that the influence of diagenesis is negligible (Qing and Mountjoy 1994; Veizer et al. 1999; Wen et al. 2013). Moreover, Middle Permian dolomites to the southwest of the study area are barely affected by diagenesis ( $\mathrm{Li}$ et al. 2017b), which is consistent with our finding. Therefore, the $\delta^{13} \mathrm{C}$ and $\delta^{18} \mathrm{O}$ values of the dolostones represent the primary carbon and oxygen isotopic compositions.

Negative $\delta^{18} \mathrm{O}$ values of dolomite are generally related to high temperatures (Allan and Wiggins 1993). The remarkably negative $\delta^{18} \mathrm{O}$ values of the dolostones in this study are similar to those of the hydrothermalsedimentary dolostones in the Jiuquan Basin and the typical hydrothermal dolostones in both Italy and Canada but are more negative than those of the dolomitic rocks in the Lucaogou Formation and the Permian marine carbonate rocks (Fig. 7), which suggests high formation temperatures for the dolostones in this study.

To better understand the formation conditions of the dolomites in this study, a quantitative estimation of the differences in formation temperatures of the dolomite in this study and the penecontemporaneous dolomite in the dolomitic rocks based on the $\delta^{18} \mathrm{O}$ values was performed. The precipitation temperature of dolomite can be calculated according to the functional relationship between the fractionation factor of the dolomite-fluid system and the temperature, $1000 \times \ln \alpha=3.14 \times 10^{6} \times$ $\mathrm{T}^{-2}-2$ (Land 1983), where $\alpha=\left(1+\delta^{18} \mathrm{O}_{\text {dolomite }} / 1000\right) /$ $\left(1+\delta^{18} \mathrm{O}_{\text {fluid }} / 1000\right)$, in which $\alpha$ is the fractionation factor and $\mathrm{T}$ is thermodynamic temperature. Obviously, the values of $\delta^{18} \mathrm{O}_{\text {dolomite }}$ and $\delta^{18} \mathrm{O}_{\text {fluid }}$ are needed for the calculation of temperature. Because of the lack of fluid inclusions in the micro-crystalline dolomite, it is difficult to constrain either the temperature or the $\delta^{18} \mathrm{O}_{\text {fluid }}$ value. However, we can make a rough estimation of the formation temperature of the dolomite based on hypothetical values of $\delta^{18} \mathrm{O}_{\text {fluid }}$. We adopted $0.82 \%$, the $\delta^{18} \mathrm{O}_{\text {SMOW }}$ value of the water in the surface mud at the bottom of Qarham Salt Lake (Xiao 1995), which has an environment similar to that of the Permian Lucaogou palaeolake in the Jimusar Sag (Zhang et al. 2018), as the hypothetical value for the palaeolake water. The palaeolake also received intermittent seawater input as it was an offshore lacustrine environment (Bian et al. 2010; Kuang et al. 2012; Yang et al. 2019); therefore, the palaeolake water is expected to have had an oxygen isotopic composition similar to that of seawater, whose $\delta^{18} \mathrm{O}_{\text {SMOW }}$ value has remained at $\sim 0 \%$ since the Neoproterozoic (Muehlenbachs 1998; Hodel et al. 2018; Ryb and Eiler 2018). Thus, we suggest that $0.82 \%$ is a reasonable hypothetical $\delta^{18} \mathrm{O}_{\mathrm{SMOW}}$ value for the parent water of the penecontemporaneous dolomite for such an estimation. With regard to the $\delta^{18} \mathrm{O}$ value of the oreforming fluid of the hydrothermal-sedimentary dolomite, 


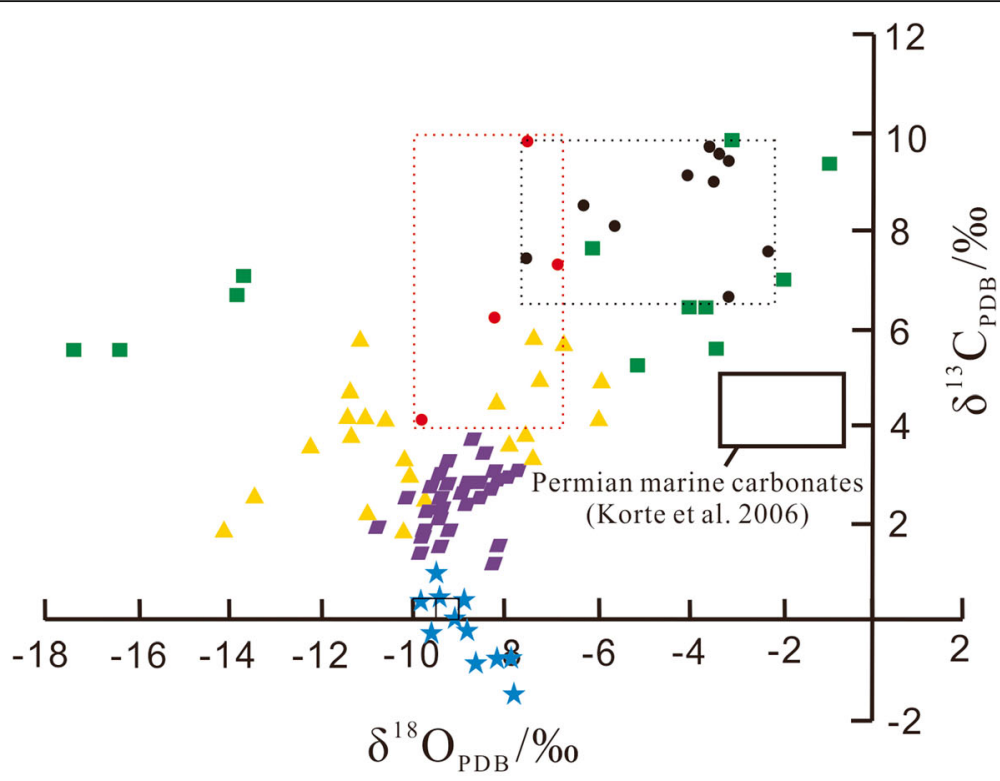

- Dolostones in this study

Dolomitic rocks/dolostones in Lucaogou Formation in study area (Zhang et al. 2018)

$\triangle$ Hydrothermal-sedimentary dolostones in Jiuquan Basin (Wen et al. 2013)

n Hydrothermal-sedimentary dolostones in Santanghu Basin (Jiao 2017)

$\star \quad$ Hydrothermal dolostones in southwestern Sardinia, Italy (Boni et al. 2000)

- Hydrothermal dolostones in Western Canada Sedimentary Basin (Al-Aasm 2003)

Fig. 7 Characteristics of carbon and oxygen isotopes of dolostones and dolomitic rocks in the Middle Permian Lucaogou Formation in Jimusar Sag, eastern Junggar Basin, and other two representative hydrothermal-sedimentary dolostones

it is difficult to determine a specific hypothetical value because the source of the fluid is still an open question. If the hydrothermal fluid was derived from the lake water with a deep circulation path (Li et al. 2017a), it is expected to have a more positive $\delta^{18} \mathrm{O}$ value than the lake water due to fluid-rock reactions (e.g., Craig 1963; Pope et al. 2009). There would also be a positive shift in the oxygen isotopic composition of the hydrothermal fluid if mantle-derived fluids participated (Taylor 1997; Valley et al. 1986), as suggested by Jiang et al. (2015). Therefore, we used $0.82 \%$ as the minimum value of $\delta^{18} \mathrm{O}_{\mathrm{SMOW}}$ for the ore-forming fluid to calculate the lowest formation temperature of the dolomite in this study. The average $\delta^{18} \mathrm{O}_{\text {SMOW }}$ value of modern black smoker

Table 7 Electron microprobe data of chemical composition (\%) of analcimes in the analcime-feldspar dolostone (AFD) of the Middle Permian Lucaogou Formation in Jimusar Sag, eastern Junggar Basin

\begin{tabular}{llllllllllll}
\hline Mineral & $\mathrm{Na}_{2} \mathrm{O}$ & $\mathrm{MgO}$ & $\mathrm{SiO}_{2}$ & $\mathrm{Al}_{2} \mathrm{O}_{3}$ & $\mathrm{CaO}$ & $\mathrm{FeO}$ & $\mathrm{MnO}$ & $\mathrm{K}_{2} \mathrm{O}$ & $\mathrm{NiO}$ & $\mathrm{Cr}_{2} \mathrm{O}_{3}$ & $\mathrm{Si} / \mathrm{Al}$ \\
\hline Analcime & 9.738 & 0.036 & 59.932 & 20.387 & 0.000 & 0.000 & 0.075 & 0.018 & 0.000 & 0.000 & 2.494 \\
& 10.607 & 0.017 & 59.105 & 20.355 & 0.000 & 0.043 & 0.062 & 0.030 & 0.019 & 0.003 & 2.463 \\
& 12.659 & 0.004 & 56.423 & 21.792 & 0.000 & 0.044 & 0.012 & 0.014 & 0.000 & 0.000 & 2.197 \\
& 11.385 & 0.008 & 57.961 & 21.502 & 0.016 & 0.065 & 0.000 & 0.009 & 0.030 & 0.000 & 2.287 \\
& 11.449 & 0.007 & 57.192 & 22.539 & 0.010 & 0.005 & 0.100 & 0.086 & 0.007 & 0.000 & 2.153 \\
& 12.300 & 0.015 & 57.041 & 20.013 & 0.000 & 0.043 & 0.006 & 0.024 & 0.028 & 0.009 & 2.418 \\
Average & 11.356 & 0.015 & 57.942 & 21.098 & 0.004 & 0.033 & 0.043 & 0.030 & 0.014 & 0.002 & 2.335 \\
\hline
\end{tabular}




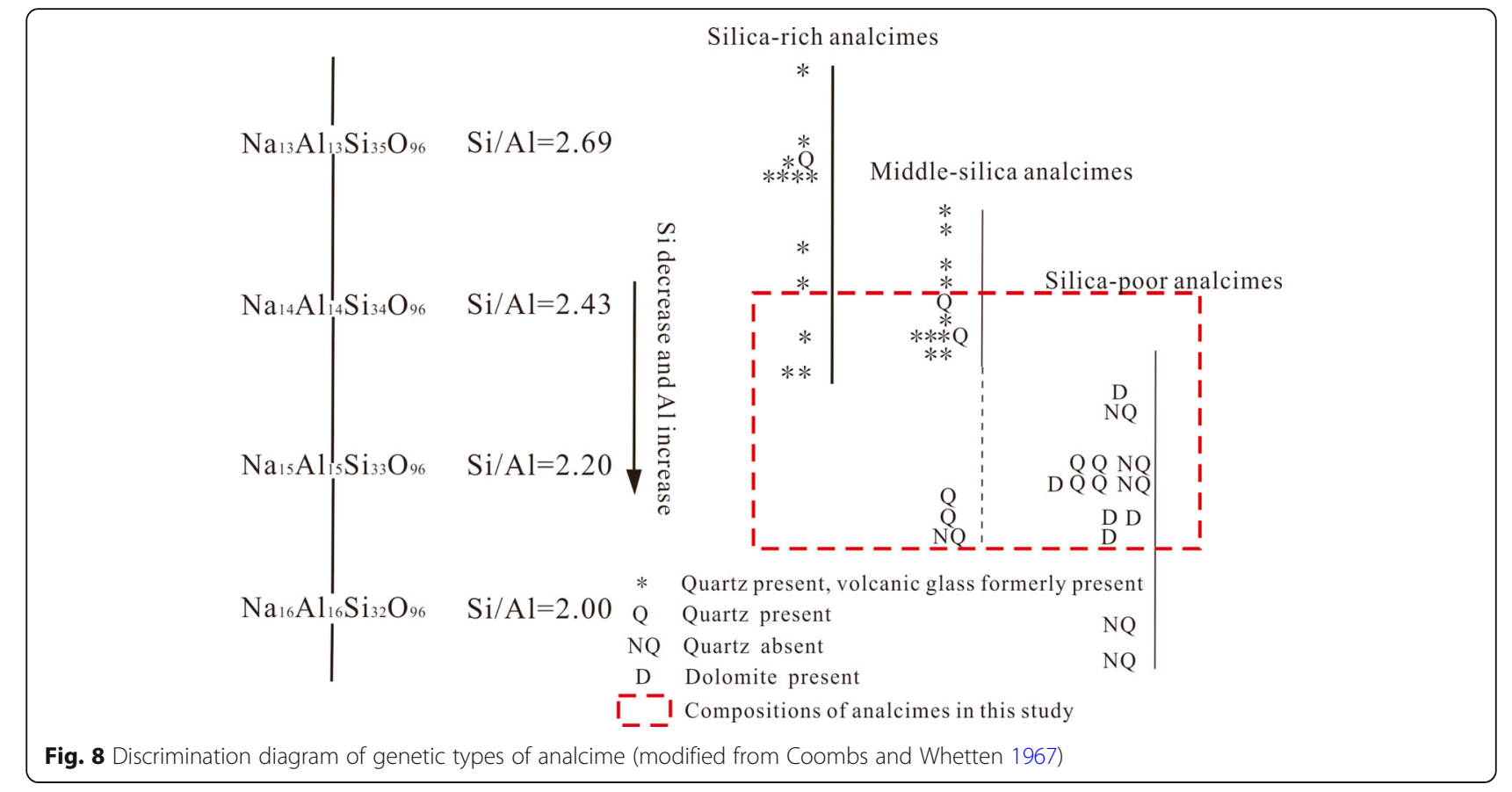

fluids $(0.91 \%$ ) compiled by Hodel et al. (2018) supports the validity of this hypothetical value. Using this hypothetical $\delta^{18} \mathrm{O}_{\text {SMOW }}$ value for the parent water of both the penecontemporaneous dolomite in the dolomitic rocks and dolomite in this study, their formation temperatures were estimated (Table 9). The results show that the formation temperatures of the dolostones in this study are at least $25^{\circ} \mathrm{C}$ higher than those of the dolomitic rocks in the Lucaogou Formation. It is noteworthy that the results are only used to evaluate the difference in formation temperatures of the dolostones and dolomitic rocks, instead of representing the real formation temperatures of the dolomites.

The $\delta^{13} \mathrm{C}$ values of the dolomitic rocks in the study area are positive, which is attributed to the depletion of ${ }^{12} \mathrm{C}$ in the lake water by exceptionally high biological production, as revealed by the organic-rich strata (Zhang et al. 2000, 2018). The dolostones in this study also have positive $\delta^{13} \mathrm{C}$ values. This is likely because the lake water played a role in dolomite formation by the way proposed by Li et al. (2017a), which seems to support the second inferred source of mantle-derived materials revealed by the ${ }^{87} \mathrm{Sr} /{ }^{86} \mathrm{Sr}$ ratios. The relatively negative $\delta^{13} \mathrm{C}$ values of the hydrothermal dolomites in Italy and Canada are related to the carbon isotopic compositions of the original rock (Boni et al. 2000) and the diagenesis fluid with negative $\delta^{13} \mathrm{C}$ values (Al-Aasm 2003), respectively.

\subsection{Formation mechanism}

Based on the above discussion and the fact that the hydrothermal activity was intense in the palaeolake bottom in the Middle Permian Junggar Basin ( $\mathrm{Li}$ et al. 2017a; Liu et al. 2018, 2019), we speculate that the AFD, $\mathrm{SD}$ and BAD are lacustrine hydrothermal-sedimentary dolostones that formed syn-depositionally. The involvement of mantle-derived materials in the ore-forming fluid is indicated by the strontium isotopic compositions. In addition, as revealed by the oxygen isotopic compositions, the formation temperatures of the dolomites are markedly higher than those of the dolomites in the dolomitic rocks in the Lucaogou Formation. We suggest that the kinetic barriers of dolomite formation were overcome by the high temperatures of the hydrothermal fluid, and the high $\mathrm{CO}_{3}{ }^{2-} / \mathrm{Ca}^{2+}$ ratio of the palaeo-saltlake water under an arid climate (Bian et al. 2010; Carroll et al. 2010; Jiang et al. 2015; Zhang et al. 2018) and the $\mathrm{Mg}^{2+}$ and $\mathrm{Fe}^{2+}$ contents in the hydrothermal fluid met the solution compositional requirements for

Table 8 Electron microprobe data of chemical composition (\%) of buddingtonites in the Middle Permian Lucaogou Formation in Jimusar Sag, eastern Junggar Basin

\begin{tabular}{|c|c|c|c|c|c|c|c|c|c|c|c|c|}
\hline Mineral & Analysis point number & $\mathrm{N}_{2} \mathrm{O}_{5}$ & $\mathrm{Na}_{2} \mathrm{O}$ & $\mathrm{SrO}$ & $\mathrm{SiO}_{2}$ & $\mathrm{Al}_{2} \mathrm{O}_{3}$ & $\mathrm{MgO}$ & TFeO & $\mathrm{CaO}$ & $\mathrm{K}_{2} \mathrm{O}$ & $\mathrm{TiO}_{2}$ & $\mathrm{BaO}$ \\
\hline Buddingtonite in the AFD & 6 & 5.827 & 0.054 & 0.365 & 62.093 & 18.001 & 0.006 & 0.030 & 0.000 & 8.822 & 0.004 & 0.274 \\
\hline Buddingtonite in the BAD & 11 & 6.990 & 0.060 & 0.408 & 63.334 & 18.362 & 0.006 & 0.058 & 0.013 & 8.500 & 0.004 & 0.258 \\
\hline
\end{tabular}


Table 9 Calculation of formation temperature of dolomites in the Middle Permian Lucaogou Formation in Jimusar Sag, eastern Junggar Basin

\begin{tabular}{llll}
\hline Sample number & Lithology & $\begin{array}{l}\delta^{18} \mathrm{O}_{\mathrm{PDB}} \\
(\% 0)\end{array}$ & $\begin{array}{l}\text { Formation temperature of the dolomites }\left({ }^{\circ} \mathrm{C}\right) \\
\delta^{18} \mathrm{O}_{\text {fluid }}(\mathrm{SMOW})=0.82 \% 0\end{array}$ \\
\hline Jm37-1 & AFD & -8.22 & 93.80 \\
$\mathrm{Jm} 37-2$ & & -6.86 & 83.47 \\
$\mathrm{Jm} 37-3$ & $\mathrm{SD}$ & -7.59 & 88.90 \\
$\mathrm{Jm} 174-\mathrm{A}$ & $\mathrm{BAD}$ & -9.81 & 107.11 \\
Average & & -8.12 & 93.32 \\
Dolomitic rocks $(n=7)$ (Zhang et al. 2018$)$ & -4.72 & 68.87 \\
\hline
\end{tabular}

dolomite formation. Consequently, dolomite eventually formed. The possible genetic models of the three dolostones in this study are proposed below.

Before the eruption of the hydrothermal fluid, the formation of high-magnesium calcite was driven by microbial metabolism in the pores of sediments on the lake bottom. Penecontemporaneous dolomite formed by replacement of the calcite (Fig. 9a). When the hydrothermal fluid erupted, its physico-chemical properties changed rapidly due to the abrupt decreases in temperature and pressure. A vapour film formed at the interface of the fluid and the lake water, which preserved the high temperatures to some extent (Kokelaar 1982; White 2000; Jiao et al. 2017b). Under these conditions, euhedral-subhedral analcime crystallized (Fig. 9b). Then, albite and potassium feldspar crystallized and cemented the analcime as the temperature decreased. The potassium ions in the feldspar were then replaced with ammonium ions in the subsequent fluid, forming buddingtonite (Fig. 3i). After that, hydrothermal fluid continued to erupt and influenced large amounts of high-magnesium calcite in the sediment pores. When the alkalinity of the fluid was adequate for dolomite formation, proto-dolomite crystallized on the surface of the
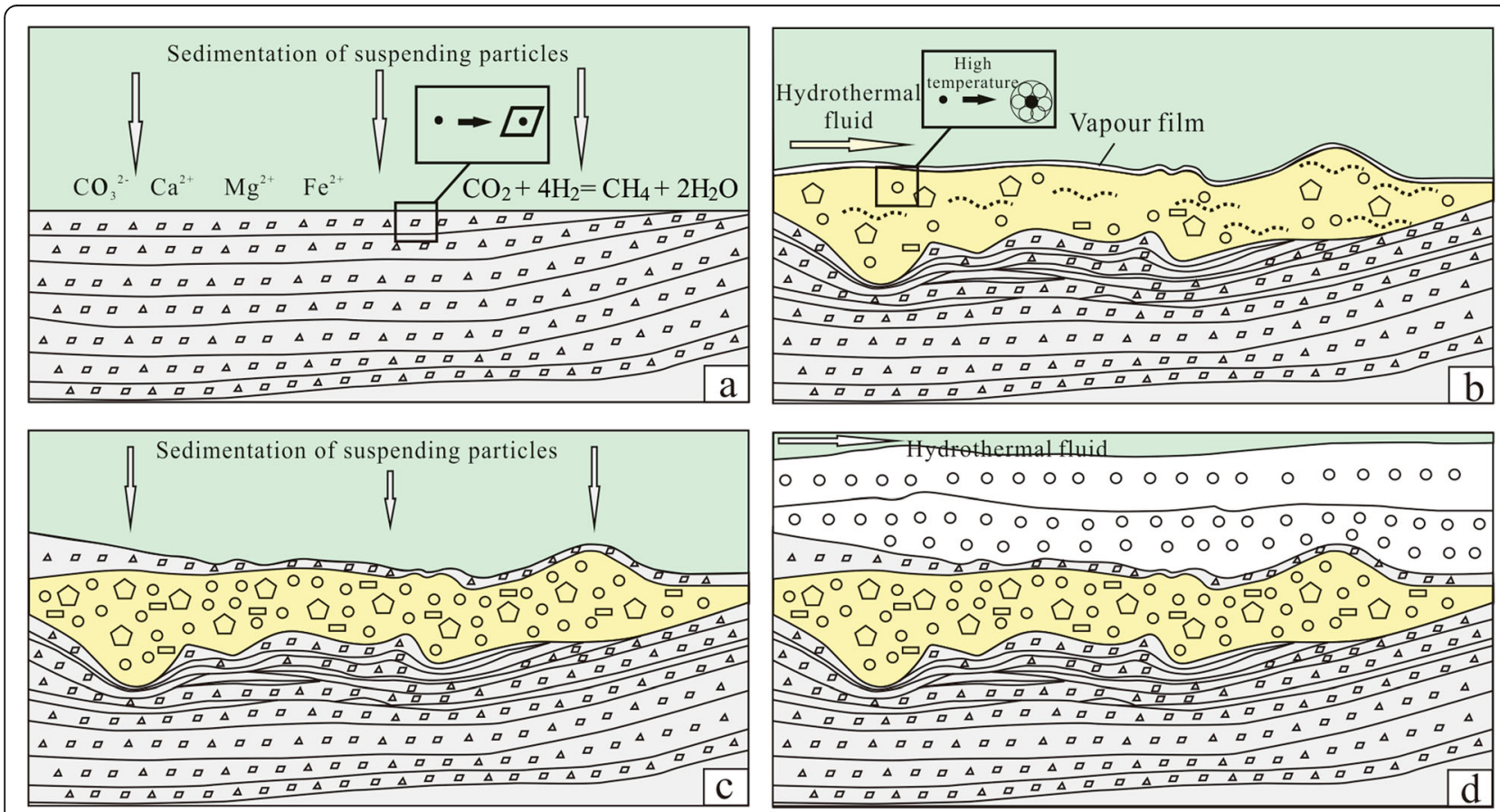

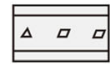

Tuffaceous dolostone

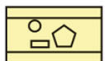

Analcime-albite dolostone

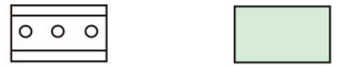

Dolotone
Salt lake water

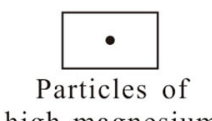

high-magnesium calcite

\section{$\bullet$}

Euhedral dolomites

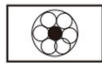

Spherical dolomites

Fig. 9 Genetic model of the analcime-feldspar dolostone (AFD) in the Middle Permian Lucaogou Formation in Jimusar Sag, Junggar Basin 
high-magnesium calcite via spherulitic growth (Rodriguez-Blanco et al. 2015) through the growth front nucleation mechanism (Gránásy et al. 2005) (Fig. 9b) and formed assemblages surrounding the analcimefeldspar assemblages (Fig. 3c-d). The mineral crystallization sequence of the AFD was analcime $\rightarrow$ albite and potassium feldspar $\rightarrow$ buddingtonite $\rightarrow$ dolomite. Notably, the subaqueous eruption of hydrothermal fluid could occur in multiple phases due to the water pressure (Fisher and Schmincke 2012). A hiatus probably occurred, as indicated by the deposition of the dark thin layer of clasts on top of the AFD (Figs. 3a and 9c). Subsequently, dolostone formed above this layer when the next phase of hydrothermal activity dominated by the crystallization of dolomite began (Figs. $3 \mathrm{~b}$ and 9d). When potassium feldspar clasts on the lake bottom were influenced by the fluid, buddingtonite formed at the edges of the potassium feldspar grains (Fig. 3k). In addition, albite pyroclasts were replaced by dolomites at high temperatures (Fig. 3l-m).

If a hydrothermal liquid is rich in silica, it first turns into a colloid during cooling. In this case, dolomite precipitated as spherulitic assemblages, and chalcedony crystallized and cemented the dolomite (Fig. 4). The mineral crystallization succession of the SD was dolomite $\rightarrow$ chalcedony.

When the fluid brought abundant ammonium ions from organic matter in the lower strata, the potassium feldspar influenced by the fluid changed to buddingtonite (Fig. 10a), and buddingtonite spherulites formed (Figs. 5c-d, f and 10b) (the specific mechanism needs to be studied further). Sedimentation and sorting of buddingtonite spherulites seemed to have proceeded in an aqueous environment, resulting in a normal graded sequence (Figs. 5c-d and 10c). Additionally, dolomite microspherulites crystallized on the surfaces of high-magnesium calcite. Then, albite crystallized and cemented the buddingtonite spherulites and the dolomite microspherulites (Figs. 5e and 10bc). Authigenic albite developed locally due to heterogeneity in the fluid (Fig. 5g-h). The mineral crystallization succession of the BAD was buddingtonite $\rightarrow$ dolomite $\rightarrow$ albite.

\subsection{Geological significance}

A lacustrine environment is more conductive to the formation of primary dolomites than a marine environment due to the high alkalinity of salt lake water and the induction of microbial organisms (Last 1990). This makes the lacustrine environment a natural laboratory for research into the dolomite problem, and there have been many studies on lacustrine dolomite (e.g., Del Cura et al. 2001; Shaked Gelband et al. 2019). On the other hand, hydrothermal dolomites can form when a hydrothermal fluid ascending from deep encounters thick layers of limestones (e.g., Boni et al. 2000; Feng et al. 2017). What happens if such a fluid erupts at the bottom of a salt lake? Hydrothermal-sedimentary dolomite connects these processes. We believe that hydrothermal-sedimentary dolomite is an important genetic type of dolomite, and this

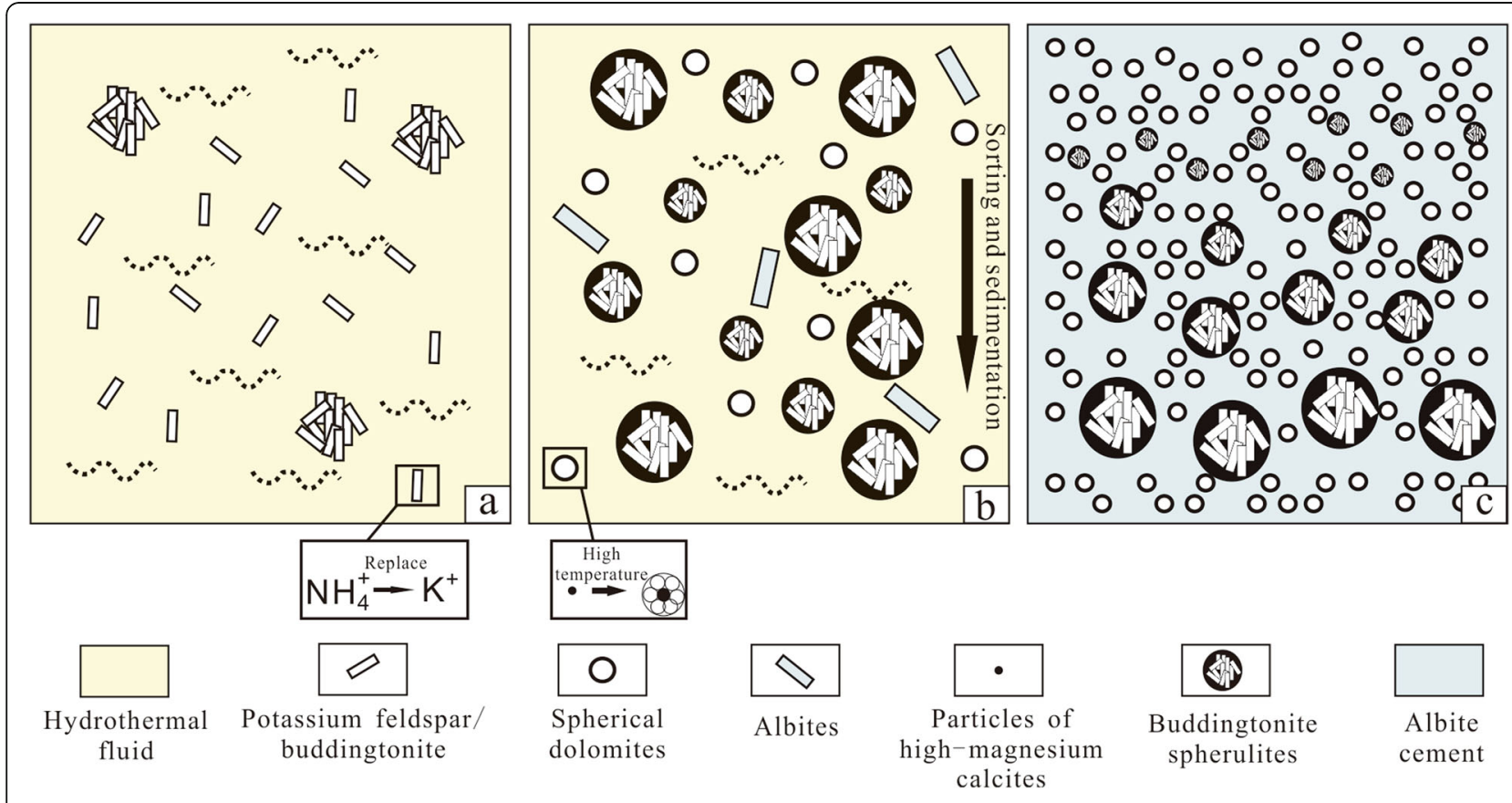

Fig. 10 Genetic model of the buddingtonite-albite dolostone (BAD) in the Middle Permian Lucaogou Formation in Jimusar Sag, Junggar Basin 
study can help increase the awareness of this understudied type of dolomite.

Furthermore, syn-sedimentary hydrothermal activity at the lake bottom could facilitate the circulation of lake water and nutrients, such as phosphorus and nitrogen, making them available to organisms. Consequently, the biological productivity of the lake may be promoted, resulting in an increase in the organic carbon input to the sediments (Zhang et al. 2010; Liu et al. 2019; You et al. 2019; Jiao et al. 2020). The Lucaogou Formation in the Junggar Basin is thought to be one of the best source rocks in the world (Graham et al. 1990; Carroll et al. 1992). The contemporary hydrothermal activity may be partly responsible for the exceedingly high organic carbon contents (Liu et al. 2019).

Previously reported hydrothermal-sedimentary rocks are characterized by special mineral assemblages and macro-scale structures. In contrast, the features of the hydrothermal-sedimentary dolomites in this study are mostly present at the micro-scale, which implies that more hydrothermal-sedimentary dolomites may exist in lake basins with similar tectonic settings and sedimentary environments. We highlight the importance and urgency of the micro-scale petrographical study of this kind of dolomites.

\section{Conclusions}

The AFD, SD and BAD in the Middle Permian Lucaogou Formation in the Jimusar Sag, eastern Junggar Basin, Northwest China, are hydrothermalsedimentary dolostones. The dolomite is relatively poorly ordered proto-dolomite with a spherical or sub-spherical morphology and is similar to hightemperature synthetic dolomite. Furthermore, the dolomite coexists with hydrothermal minerals, including analcime, buddingtonite, albite and chalcedony. Albite clasts are replaced by dolomite, indicating high-temperature conditions. The remarkably low strontium isotopic compositions (with an average of 0.705687) indicate that mantle-derived materials may have involved in the ore-forming fluid. The dolostones have positive $\delta^{13} \mathrm{C}_{\mathrm{PDB}}$ values (with an average of $6.94 \%$ ) and negative $\delta^{18} \mathrm{O}_{\mathrm{PDB}}$ values (with an average of $-8.12 \%$ ). The $\delta^{18} \mathrm{O}$ data estimate that the formation temperature of the dolomite is at least $\sim 25^{\circ} \mathrm{C}$ higher than those of the dolomitic rocks in the Lucaogou Formation in the study area. Based on the formation temperature, it can be concluded that the dolomites and the associated minerals precipitated from hydrothermal fluid erupting at the lake bottom. The kinetic barriers of dolomite formation are overcome by the high temperature of the hydrothermal fluid. Additionally, the high $\mathrm{CO}_{3}{ }^{2-} / \mathrm{Ca}^{2+}$ ratios of the palaeo-salt-lake water and the $\mathrm{Mg}^{2+}$ and $\mathrm{Fe}^{2+}$ contents of the hydrothermal fluid meet the solution compositional requirements for dolomite formation. We suggest that the hydrothermal-sedimentary dolomite is an important genetic type of dolomite, and this study may help increase the awareness of this understudied type of dolomite.

\section{Abbreviations}

AFD: Analcime-feldspar dolostone; BAD: Buddingtonite-albite dolostone;

EDS: Energy-dispersive spectroscopy; EPMA: Electron probe microanalysis; SD: Silicic dolostone; SEM: Scanning electron microscope; XRD: X-ray diffraction

\section{Acknowledgements}

The authors would like to thank Ning-Chao Zhou in Experimental Test Center of Xi'an Center of Geological Survey for instruction and help in the electron probe microanalysis experiment. We thank Dr. Tao Hu in China University of Petroleum (Beijing) for helping with the collection of basic data. We also thank Prof. Zeng-Zhao Feng, Prof. Da-Kang Zhong, and other three anonymous reviewers as well as editors for their comments and suggestions which have greatly improved this paper.

\section{Authors' contributions}

SZ and YQL designed the research. SZ wrote the original manuscript, prepared the samples for experiments and made the graphs. HL, XJ and DWZ contributed to the interpretation of experiment results. The authors read and approved the final manuscript.

\section{Funding}

This study was supported by the National Natural Science Foundation of China (Grant Nos. 41572086, 41802120).

\section{Availability of data and materials}

All data generated or analysed during this study are included in this published paper.

\section{Competing interests}

The authors declare that they have no competing interests.

\section{Author details}

${ }^{1}$ State Key Laboratory of Continental Dynamics, Northwest University, Xi'an 710069, Shaanxi Province, China. 'Department of Geology, Northwest University, Xi'an 710069, Shaanxi Province, China. ${ }^{3}$ Key Laboratory of Alpine Ecology, Institute of Tibetan Plateau Research, Chinese Academy of Sciences, Beijing 100101, China. ${ }^{4}$ University of Chinese Academy of Sciences, Beijing 100049, China.

Received: 22 November 2019 Accepted: 28 July 2020

Published online: 26 August 2020

\section{References}

Al-Aasm, I.S. 2003. Origin and characterization of hydrothermal dolomite in the Western Canada Sedimentary Basin. Journal of Geochemical Exploration 78: 9-15.

Allan, J.R., and W.D. Wiggins. 1993. Dolomite reservoirs: Geochemical techniques for evaluating origin and distribution. American Association of Petroleum Geologists 14: 262-263.

Arvidson, R.S., and F.T. Mackenzie. 1999. The dolomite problem: Control of precipitation kinetics by temperature and saturation state. American Journal of Science 299: 257-288.

Barker, D.S. 1964. Ammonium in alkali feldspars. American Mineralogist: Journal of Earth and Planetary Materials 49: 851-858.

Bian, W., J. Hornung, Z. Liu, P. Wang, and M. Hinderer. 2010. Sedimentary and palaeoenvironmental evolution of the Junggar Basin, Xinjiang, Northwest China. Paleobiodiversity and Paleoenvironments 90: 175-186.

Boni, M., G. Parente, T. Bechstaedt, B. De Vivo, and A. lannace. 2000. Hydrothermal dolomites in SW Sardinia (Italy): Evidence for a 
widespread late-Variscan fluid flow event. Sedimentary Geology 131: $181-200$.

Bontognali, T.R. 2019. Anoxygenic phototrophs and the forgotten art of making dolomite. Geology 47 (6): 591-592.

Cao, Z., G. Liu, Y. Kong, C. Wang, Z. Niu, J. Zhang, C. Geng, X. Shan, and Z. Wei. 2016. Lacustrine tight oil accumulation characteristics: Permian Lucaogou formation in Jimusaer Sag, Junggar Basin. International Journal of Coal Geology 153: 37-51.

Carroll, A.R., S.C. Brassell, and S.A. Graham. 1992. Upper Permian lacustrine oil shales, southern Junggar Basin, Northwest China. American Association of Petroleum Geologists Bulletin 76: 1874-1902.

Carroll, A.R., S.A. Graham, M.S. Hendrix, D. Ying, and D. Zhou. 1995. Late Paleozoic tectonic amalgamation of northwestern China: Sedimentary record of the northern Tarim, northwestern Turpan, and southern Junggar basins. Geological Society of American Bulletin 107: 571-594.

Carroll, A.R., S.A. Graham, and M.E. Smith. 2010. Walled sedimentary basin of China. Basin Research 22: 17-32.

Chang, H.L., R.C. Zheng, C.L. Guo, and H.G. Wen. 2016. Characteristics of rare earth elements of exhalative rock in Fengcheng formation, northwestern margin of Jungger Basin. Geological Review 62: 550-568 (in Chinese with English abstract).

Charlou, J.L., J.P. Donval, Y. Fouquet, P. Jean-Baptiste, and N. Holm. 2002. Geochemistry of high $\mathrm{H}_{2}$ and $\mathrm{CH}_{4}$ vent fluids issuing from ultramafic rocks at the rainbow hydrothermal field $\left(36^{\circ} 14^{\prime} \mathrm{N}, \mathrm{MAR}\right)$. Chemical Geology 191: 345-359.

Chen, Z.P., Z.L. Ren, C.Y. Yu, Q. Kai, W.B. Ren, Y. Yang, and Q. Ma. 2018. Characteristics and genetic analysis of hydrothermal sediment of Lower Cretaceous in Hari depression sag, Yin'e Basin. Earth Science 43: 19411956 (in Chinese with English abstract).

Coombs, D.S., and J.T. Whetten. 1967. Composition of analcime from sedimentary and metamorphic rocks. Geological Society of American Bulletin 78: 269-282.

Craig, H. 1963. The isotopic geochemistry of water and carbon in geothermal areas. In Nuclear geology on geothermal areas, ed. E. Tongiorgi, 17-53. Pisa: Consiglio Nazional delle Ricerche, Laboratorio di Geologia Nucleare.

Dai, C.C., R.C. Zheng, H.G. Wen, G.M. Lei, and C.H. Xie. 2008. Origin of lacustrine dolomite in the Paleogene Shahejie formation of Liaodongwan Basin, China. Journal of Chengdu University of Technology (Science \& Technology Edition) 35: 187-193 (in Chinese with English abstract).

Del Cura, M.A.G., J.P. Calvo, S. Ordóñez, B.F. Jones, and J.C. Cañaveras. 2001. Petrographic and geochemical evidence for the formation of primary, bacterially induced lacustrine dolomite: La Roda 'white earth' (Pliocene, Central Spain). Sedimentology 48: 897-915.

Dolomieu, D.G.D. 1791. Sur un genre de pierres calcaires très-Peu effervescentes avec les acides of phosphorescentes par la collision. Journal de Physique 39: 3-10.

Eickmann, B., W. Bach, M. Rosner, and J. Peckmann. 2009. Geochemical constraints on the modes of carbonate precipitation in peridotites from the Logatchev Hydrothermal Vent Field and Gakkel Ridge. Chemical Geology 268 (1-2): 97-106.

Erd, R.C., D.E. White, J.J. Fahey, and D.E. Lee. 1964. Buddingtonite, an ammonium feldspar with zeolitic water. American Mineralogist: Journal of Earth and Planetary Materials 49: 831-850.

Fang, S.H., C.Z. Jia, Z.J. Guo, Y. Song, H.M. Xu, and L.J. Liu. 2006. New view on the Permian evolution of the Junggar basin and its implications for tectonic evolution. Earth Science Frontiers 13: 108-121 (in Chinese with English abstract).

Faure, G. 1986. Principles of isotope geology. 2nd ed, 160-230. New York: Wiley.

Feng, M., P. Wu, Z. Qiang, X. Liu, Y. Duan, and M. Xia. 2017. Hydrothermal dolomite reservoir in the Precambrian Dengying formation of central Sichuan Basin, southwestern China. Marine and Petroleum Geology 82: 206-219.

Fisher, R.V., and H.U. Schmincke. 2012. Pyroclastic rocks, 265-296. Berlin: Springer Science \& Business Media.
Fu, R., R.C. Zheng, H.L. Chang, L.Q. Qi, H.G. Wen, and Y. Li. 2015. Lacustrine "white smoke type" exhalative rock - A new type of tight oil reservoir: A case study from lower Permian Fengcheng formation in Urho area, western margin of Junggar Basin. Lithologic Reservoirs 27: 32-42 (in Chinese with English abstract).

Gaines, A.M. 1977. Protodolomite redefined. Journal of Sedimentary Research 47: $543-546$

Graham, S.A., S. Brassell, A.R. Carroll, X. Xiao, G. Demaison, C.L. McKnight, Y. Liang, J. Chu, and M.S. Hendrix. 1990. Characteristics of selected petroleum source rocks, Xianjiang Uygur Autonomous Region, Northwest China. American Association of Petroleum Geologists Bulletin 74: 493-512.

Gránásy, L., T. Pusztai, G. Tegze, J.A. Warren, and J.F. Douglas. 2005. Growth and form of spherulites. Physical Review E 72: 011605.

Gregg, J.M., D.L. Bish, S.E. Kaczmarek, and H.G. Machel. 2015. Mineralogy, nucleation and growth of dolomite in the laboratory and sedimentary environment: A review. Sedimentology 62: 1749-1769.

Guo, Q., D.K. Zhong, F.D. Zhang, X.G. Liu, L.X. Fan, and J.J. Li. 2012. Origin of the lower cretaceous lacustrine dolostones in Baiyinchagan Sag of Erlian Basin, Inner Mongolia. Journal of Palaeogeography (Chinese Edition) 14: 59-68 (in Chinese with English abstract).

Hallam, M., and H.P. Eugster. 1976. Ammonium silicate stability relations. Contributions to Mineralogy and Petrology 57: 227-244.

Hodel, F., M. Macouin, R. Trindade, A. Triantafyllou, J. Ganne, V. Chavagnac, J. Berger, M. Rospabé, C. Destrigneville, and J. Carlut. 2018. Fossil black smoker yields oxygen isotopic composition of Neoproterozoic seawater. Nature Communications 9 (1): 1-7.

Hori, H. 1986. Ammonioleucite, a new mineral from Tatarazawa, Fujioka, Japan. American Mineralogist 71: 1022-1027.

llich, M. 1974. Hydrothermal-sedimentary dolomite: The missing link? American Association of Petroleum Geologists Bulletin 58: 1331-1347.

Jiang, Y.Q., Y.Q. Liu, Z. Yang, Y. Nan, R. Wang, P. Zhou, Y.J. Yang, J.Y. Kou, and N.C. Zhou. 2015. Characteristics and origin of tuff-type tight oil in Jimusar Depression Sag, Junggar Basin, NW China. Petroleum Exploration \& Experiment 42: 741-749.

Jiao, X. 2017. Features and forming mechanism of magmatic-hydrothermal exhalative sedimentary rocks in Permian Lucaogou Formation, Santanghu Basin, Xinjiang. [Ph.D. Thesis], 59. China: Northwest University (in Chinese with English abstract).

Jiao, X., Y. Liu, W. Yang, D. Zhou, H. Li, Y. Nan, and M. Jin. 2018. A magmatichydrothermal lacustrine exhalite from the Permian Lucaogou formation, Santanghu Basin, NW China - The volcanogenic origin of fine-grained clastic sedimentary rocks. Journal of Asian Earth Sciences 156: 11-25.

Jiao, X., Y.Q. Liu, M.Q. Jin, and D.W. Zhou. 2017a. Thin bed magmatichydrothermal dolomitic exhalative sedimentary rocks in Santanghu Basin, Xinjiang Province. Acta Sedimentologica Sinica 35: 1087-1096 (in Chinese with English abstract).

Jiao, X., Y.Q. Liu, W. Yang, and D.W. Zhou. 2017b. Progress on sedimentation of subaqueous volcanic eruption. Advances in Earth Science 32: 926-936 (in Chinese with English abstract).

Jiao, X., Y.Q. Liu, W. Yang, D.W. Zhou, B. Bai, T.S. Zhang, M.R. Zhao, Z.X. Li, Z. Y. Meng, and Y.Y. Yang. 2020. Fine-grained volcanic-hydrothermal sedimentary rocks in Permian Lucaogou formation, Santanghu Basin, NW China: Implications on hydrocarbon source rocks and accumulation in lacustrine rift basins. Marine and Petroleum Geology 114: 104201.

Kelley, D.S., J.A. Karson, D.K. Blackman, G.L. Fruèh-Green, D.A. Butterfield, M.D. Lilley, E.J. Olson, M.O. Schrenk, K.K. Roe, G.T. Lebon, and P. Rivizzigno. 2001. An off-axis hydrothermal vent field near the Mid-Atlantic Ridge at $30^{\circ} \mathrm{N}$. Nature 412: 145

Kokelaar, B.P. 1982. Fluidization of wet sediments during the emplacement and cooling of various igneous bodies. Journal of the Geological Society 50: 358-367.

Korte, C., T. Jasper, H.W. Kozur, and J. Veizer. 2006. ${ }^{87} \mathrm{Sr} /{ }^{86} \mathrm{Sr}$ record of Permian seawater. Palaeogeography, Palaeoclimatology, Palaeoecology 240: 89-107.

Krohn, M.D. 1987. Near-infrared detection of ammonium minerals. Geophysics 52: 924-930. 
Krohn, M.D., C. Kendall, J.R. Evans, and T.L. Fries. 1993. Relations of ammonium minerals at several hydrothermal systems in the western US. Journal of Volcanology and Geothermal Research 56: 401-413.

Kuang, L., T. Yong, L. Dewen, Q. Chang, M. Ouyang, H. Lianhua, and L. Deguang. 2012. Formation conditions and exploration potential of tight oil in the Permian saline lacustrine dolomitic rock, Junggar Basin, NW China. Petroleum Exploration and Development 39 (6): 700-711.

Land, L.S. 1983. The application of stable isotopes to studies of the origin of dolomite and to problems of diagenesis of clastic sediments. In Stable isotopes in sedimentary geology, SEPM short course 10, ed. M.A. Authur, T. F. Anderson, I.R. Kaplan, J. Veizer, and L.S. Land, 1-22. Tulsa: Society for Sedimentary Geology.

Land, L.S. 1998. Failure to precipitate dolomite at $25^{\circ} \mathrm{C}$ from dilute solution despite 1000-fold oversaturation after 32 years. Aquatic Geochemistry 4: 361-368.

Last, W.M. 1990. Lacustrine dolomite - An overview of modern, Holocene, and Pleistocene occurrences. Earth-Sciences Review 27: 221-263.

Li, H., Y. Liu, Y. Niu, S. Feng, Y. Lei, and Y. Liu. 2017b. Comparisons on mineralogy and lithology between Paleozoic marine and lacustrine dolostones, northern China. Acta Geologica Sinica (English Edition) 91: 281-282.

Li, H., Y.Q. Liu, L.X. Zhang, X. Zhou, Y.Z. Niu, X. Li, and Y.J. Liu. 2017a. Origin and geological significance of sedimentary exhalative rocks with "porphyritic" structures in the middle Permian Pingdiquan formation, eastern Junggar Basin. Journal of Palaeogeography (Chinese Edition) 19: 211-226 (in Chinese with English abstract).

Li, J.Y., X.C. Xiao, Y.Q. Tang, M. Zhao, B.Q. Zhu, and Y.M. Feng. 1990. Main characteristics of Late Paleozoic plate tectonics in the southern part of east Junggar, Xinjiang. Geological Review 36: 305-316 (in Chinese with English abstract).

Liu, Y., D. Zhou, X. Jiao, Q. Feng, and X. Zhou. 2019. A preliminary study on the relationship between deep-sourced materials and hydrocarbon generation in lacustrine source rocks: An example from the Permian black rock series in Jimusar sag, Junggar Basin. Journal of Palaeogeography (Chinese Edition) 21 (6): 983-998 (in Chinese with English abstract).

Liu, Y.Q., X. Jiao, H. Li, M.S. Yuan, W. Yang, X.H. Zhou, H. Liang, D.W. Zhou, C. Y. Zheng, Q. Sun, and S.S. Wang. 2012. Primary dolostone formation related to mantle-originated exhalative hydrothermal activities, Permian Yuejingou section, Santanghu area, Xinjiang, NW China. Science China Earth Sciences 55 (2): 183-192.

Liu, Y.Q., H. Li, Y.S. Zhu, T. Hu, G.B. Fu, H.F. Liu, X.H. Zhou, C.Y. Zheng, and T. T. Fan. 2010. Permian lacustrine eruptive hydrothermal dolomites, Santanghu Basin, Xinjiang Province. Acta Sedimentologica Sinica 28: 861-867 (in Chinese with English abstract).

Liu, Y.Q., D.W. Zhou, Y. Nan, X. Jiao, Z.X. Li, H. Li, and X.H. Zhou. 2018. Permian mantle-derived carbonatite originated exhalative sedimentary rocks in North Xinjiang. Journal of Palaeogeography (Chinese Edition) 20: 49-63 (in Chinese with English abstract).

Lu, M.A. 2007. Multistage evolution of the basin-and-range structure of the eastern section of the Tienshan Mountains. [Ph.D. Thesis], 394. Institution of Geology, China Earthquake Administration, China (in Chinese with English abstract).

Luczaj, J.A., W.B. Harrison III, and N. Smith Williams. 2006. Fractured hydrothermal dolomite reservoirs in the Devonian Dundee formation of the Central Michigan Basin. American Association of Petroleum Geologists Bulletin 90: 1787-1801.

Machel, H.G. 2004. Concepts and models of dolomitization - A critical reappraisal. In The geometry and petrogenesis of dolomite hydrocarbon reservoirs, ed. C.J.R. Braithwaite, G. Rizzi, and G. Darke, vol. 235, 7-63. London: Geological Society, Special Publications.

Machel, H.G., and J. Lonnee. 2002. Hydrothermal dolomite - A product of poor definition and imagination. Sedimentary Geology 152: 163-171.

Muehlenbachs, K. 1998. The oxygen isotopic composition of the oceans, sediments and the seafloor. Chemical Geology 145 (3-4): 263-273.

Nishiyama, T. 1990. CO $\mathrm{CO}_{2}$-metasomatism of a metabasite block in a serpentine melange from the Nishisonogi metamorphic rocks, Southwest Japan. Contributions to Mineralogy and Petrology 104: 35-46.
Palmer, M.R., and H. Elderfield. 1985. Sr isotope composition of sea water over the past 75 Myr. Nature 314: 526-528.

Pampeyan, E.H. 2010. Buddingtonite in Menlo Park, California (No. 2010-1053). US Geological Survey.

Pope, E.C., D.K. Bird, S. Arnórsson, T. Fridriksson, W.A. Elders, and G.Ó. Fridleifsson. 2009. Isotopic constraints on ice age fluids in active geothermal systems: Reykjanes, Iceland. Geochimica et Cosmochimica Acta 73 (15): 4468-4488.

Qing, H., and E.W. Mountjoy. 1994. Formation of coarsely crystalline, hydrothermal dolomite reservoirs in the Presqu'ile Barrier, Western Canada sedimentary basin. American Association of Petroleum Geologists Bulletin 78: 55-77.

Ramseyer, K., L.W. Diamond, and J.R. Boles. 1993. Authigenic K-NH4-feldspar in sandstones: A fingerprint of the diagenesis of organic matter. Journal of Sedimentary Research 63: 1092-1099.

Rodriguez-Blanco, J.D., S. Shaw, and L.G. Benning. 2015. A route for the direct crystallization of dolomite. American Mineralogist 100: 1172-1181.

Ryb, U., and J.M. Eiler. 2018. Oxygen isotope composition of the Phanerozoic Ocean and a possible solution to the dolomite problem. Proceedings of the National Academy of Sciences 115 (26): 6602-6607.

Shaked Gelband, D., Y. Edelman-Furstenberg, M. Stein, and A. Starinsky. 2019. Formation of lacustrine dolomite in the late Miocene marginal lakes of the East Mediterranean (Northern Israel). Sedimentology 66 (7): 2950-2975.

Shanks, W.C., III. 2001. Stable isotopes in seafloor hydrothermal systems: Vent fluids, hydrothermal deposits, hydrothermal alteration, and microbial processes. Reviews in Mineralogy and Geochemistry 43: 469-525.

Shao, Y., Y.Q. Yang, M. Wan, L.W. Qiu, Y.C. Cao, and S.C. Yang. 2015. Sedimentary characteristic and facies evolution of Permian Lucaogou formation in Jimusar Sag, Junggar Basin. Xinjiang Petroleum Geology 36 (6): 635-641 (in Chinese with English abstract).

Song, Y., L. Zhou, X.G. Guo, Q.S. Chang, and X.T. Wang. 2017. Characteristics and occurrence of lacustrine dolomitic tight-oil reservoir in the Middle Permian Lucaogou formation, Jimusar Sag, southeastern Junggar Basin. Acta Petrologica Sinica 33 (4): 1159-1170 (in Chinese with English abstract).

Su, C., D. Zhong, P. Qin, and A. Wang. 2020. Mineral precipitation sequence and formation of the lacustrine hydrothermal sediments in the lower cretaceous Tenggeer formation in the Baiyinchagan Sag, China. Sedimentary Geology 398: 105586

Tao, G., W.G. Yang, L.D. Zhu, Z.W. Li, L. Xie, W. Fan, Y. He, and C. Li. 2016. Lithological characteristics and sedimentary models of the lacustrine hydrothermal sedimentary rocks of the Neogene Suonahu formation on the southern edge of Qiangtang. Journal of Mineralogy and Petrology 36: 72-81 (in Chinese with English abstract).

Taylor, H.P.J. 1997. Oxygen and hydrogen isotope relationships in hydrothermal mineral deposits. In Geochemistry of hydrothermal ore deposits, ed. H.L. Barnes, 3rd ed., 229-302. New York: Wiley.

Tucker, M.E., and V.P. Wright. 1990. Carbonate sedimentology, 482. Boston: Blackwell Scientific Publications.

Valley, J.W., H.P. Taylor, and J.R. O'Neil. 1986. Stable isotopes in high temperature geological processes. Mineralogical Society of America 16: 227-271.

Veizer, J., D. Ala, K.B. Azmy, P. Bruckschen, D. Buhl, F. Bruhn, G.A.F. Carden, A. Diener, S. Ebneth, Y. Godderis, T. Jasper, C. Korte, F. Pawellek, O.G. Podlaha, and H. Strauss. 1999. ${ }^{87} \mathrm{Sr} /{ }^{86} \mathrm{Sr}, \delta^{13} \mathrm{C}$ and $\delta^{18} \mathrm{O}$ evolution of Phanerozoic seawater. Chemical Geology 161: 59-88.

Wang, J., L. Zhou, J. Mi, C. Ma, H. Yang, H. Lei, J. Chen, and J. Ren. 2019. Trace elemental geochemistry and depositional environment of shale oil reservoir rocks within the Permian Lucaogou formation, Jimusaer Sag, IOP conference series: Earth and environmental science. Bristol: IOP Publishing.

Wartes, M.A., A.R. Carroll, and T.J. Greene. 2002. Permian sedimentary record of the Turpan-Hami Basin and adjacent regions, Northwest China: Constraints on postamalgamation tectonic evolution. Geological Society of America Bulletin 114: 131-152.

Wen, H.G., R.C. Zheng, H.R. Qing, M.T. Fan, Y.N. Li, and B.S. Gong. 2013. Primary dolostone related to the cretaceous lacustrine hydrothermal 
sedimentation in Qingxi Sag, Jiuquan Basin on the northern Tibetan Plateau. Science China Earth Sciences 56: 2080-2093.

White, J.D.L. 2000. Subaqueous eruption-fed density currents and their deposits. Precambrian Research 101: 87-109.

Xi, K.L., Y.C. Cao, R.K. Cao, Y. Shao, X.J. Xue, X.J. Wang, Y. Gao, and J. Zhang. 2015. Rock types and characteristics of tight oil reservoir in Permian Lucaogou formation, Jimsar Sag. Acta Petrolei Sinica 36 (12): 1495-1507 (in Chinese with English abstract).

Xiao, Y. 1995. Oxygen and hydrogen isotope research of different waters in Qarhan Salt Lake and lake sediments. Journal of Xiamen University (Natural Science) 34 (2): 249-255 (in Chinese with English abstract).

Yang, Y., L. Qiu, M. Wan, X. Jia, Y. Cao, D. Lei, and C. Qu. 2019. Depositional model for a salinized lacustrine basin: The permian Lucaogou formation, Jimsar sag, Junggar Basin, NW China. Journal of Asian Earth Sciences 178: 81-95.

Yang, Z., D. Zhong, F. Whitaker, Z. Lu, S. Zhang, Z. Tang, R. Liu, and Z. Li. 2020. Syn-sedimentary hydrothermal dolomites in a lacustrine rift basin: Petrographic and geochemical evidence from the lower cretaceous Erlian Basin, northern China. Sedimentology 67 (1): 305-329.

You, J., Y. Liu, D. Zhou, Q. Zheng, K. Vasichenko, and Z. Chen. 2019. Activity of hydrothermal fluid at the bottom of a lake and its influence on the development of high-quality source rocks: Triassic Yanchang formation, southern Ordos Basin, China. Australian Journal of Earth Sciences 67: 114.

Zhang, S., Y.Q. Liu, X. Jiao, D.W. Zhou, X. Zhang, and S.T. Lu. 2018. Sedimentary environment and formation mechanisim of dolomitic rocks in the Middle Permian Lucaogou Formation, Jimusar Depression Sag, Junggar Basin. Journal of Palaeogeography (Chinese Edition) 20: 49-63 (in Chinese with English abstract).

Zhang, W.Z., H. Yang, L.Q. Xie, and Y.H. Yang. 2010. Lake-bottom hydrothermal activities and their influence on high-quality source rock development: A case from Chang 7 source rocks in Ordos Basin. Petroleum Exploration and Development 37 (4): 424-429.

Zhang, X.B., Z.Y. Wang, and Y.C. Xu. 2000. Finding of the dolostones with special carbon isotopic composition and its significance. Acta Sedimentologica Sinica 18 (3): 449-452 (in Chinese with English abstract).

Zheng, R., H. Wen, Y. Li, and H. Chang. 2018. Compositions and texture of lacustrine exhalative rocks from the lower cretaceous Xiagou formation in Qingxi Sag of Jiuxi Basin, Gansu. Journal of Palaeogeography (Chinese Edition) 20 (1): 1-18 (in Chinese with English abstract).

Zheng, R.C., C.S. Wang, L.D. Zhu, H.J. Liu, G.Y. Fang, W.B. Du, C.X. Wang, and M.F. Wang. 2003. Discovery of the first example of "white smoke type" of exhalative rock (hydrothermal sedimentary dolostone) in Jiuxi Basin and its significance. Journal of Chengdu University of Technology (Science \& Technology Edition) 30: 1-8 (in Chinese with English abstract).

Zheng, R.C., H.G. Wen, M.T. Fan, M.F. Wang, G.X. Wu, and P.F. Xia. 2006. Lithological characteristics of sublacustrine white smoke type exhalative rock of the Xiagou formation in Jiuxi Basin. Acta Petrologica Sinica 22 (12): 3027-3038 (in Chinese with English abstract).

Zhong, D., Z. Jiang, Q. Guo, H. Sun, and Z. Yang. 2015. Discovery of hydrothermal dolostones in Baiyinchagan Sag of Erlian Basin, Inner Mongolia, and its geologic and mineral significance. Oil and Gas Geology 36 (4): 587-595 (in Chinese with English abstract).

Zhong, D., Z. Yang, H. Sun, and S. Zhang. 2018. Petrological characteristics of hydrothermal-sedimentary rocks: A case study of the lower cretaceous Tengger formation in the Baiyinchagan Sag of Erlian Basin, Inner Mongolia. Journal of Palaeogeography (Chinese Edition) 20: 19-32 (in Chinese with English abstract).

Zhou, D.W., Y.Q. Liu, X.J. Xing, J.R. Hao, Y.P. Dong, and Z.J. Ouyang. 2006. The paleotectonic setting reverting and regional tectonic setting tracking of basalt during Permian in Tu-Ha, Santanghu Basin in Xinjiang. Science China Earth Sciences 36 (2): 143-153.

\section{Publisher's Note}

Springer Nature remains neutral with regard to jurisdictional claims in published maps and institutional affiliations.

\section{Submit your manuscript to a SpringerOpen ${ }^{\circ}$ journal and benefit from:}

- Convenient online submission

- Rigorous peer review

- Open access: articles freely available online

- High visibility within the field

- Retaining the copyright to your article

Submit your next manuscript at $\boldsymbol{\nabla}$ springeropen.com 